\title{
DEFERRING INCOME IN EMPLOYER-SPONSORED RETIREMENT PLANS: THE DYNAMICS OF PARTICIPANT CONTRIBUTIONS
}

\author{
Karen E. Smith* \\ Richard W. Johnson \\ Leslie A. Muller \\ CRR WP 2004-20 \\ Released: August 2004 \\ Draft Submitted: May 2004 \\ Center for Retirement Research at Boston College \\ 550 Fulton Hall \\ 140 Commonwealth Ave. \\ Chestnut Hill, MA 02467 \\ Tel: 617-552-1762 Fax: 617-552-1750 \\ http://www.bc.edu/crr
}

*Karen E. Smith and Richard W. Johnson are senior research associates in the Income and Benefits Policy Center at the Urban Institute. Leslie A. Muller is an economist at the Social Security Administration. The research reported herein was supported by the Center for Retirement Research at Boston College pursuant to a grant from the U.S. Social Security Administration funded as part of the Retirement Research Consortium. The opinions and conclusions are solely those of the authors and should not be construed as representing the opinions or policy of the Social Security Administration or any agency of the Federal Government, the Center for Retirement Research at Boston College, or the Urban Institute, its boards, or its funders.

(C) 2004, by Karen E. Smith, Richard W. Johnson, and Leslie A. Muller. All rights reserved. Short sections of text, not to exceed two paragraphs, may be quoted without explicit permission provided that full credit, including (C) notice, is given to the source. 


\title{
About the Center for Retirement Research
}

The Center for Retirement Research at Boston College, part of a consortium that includes parallel centers at the University of Michigan and the National Bureau of Economic Research, was established in 1998 through a grant from the Social Security Administration. The goals of the Center are to promote research on retirement issues, to transmit new findings to the policy community and the public, to help train new scholars, and to broaden access to valuable data sources. Through these initiatives, the Center hopes to forge a strong link between the academic and policy communities around an issue of critical importance to the nation's future.

\author{
Center for Retirement Research at Boston College \\ 550 Fulton Hall \\ 140 Commonwealth Ave. \\ Chestnut Hill, MA 02467 \\ phone: 617-552-1762 fax: 617-552-1750 \\ e-mail: crr@bc.edu \\ http://www.bc.edu/crr
}

Affiliated Institutions:

American Enterprise Institute

The Brookings Institution

Massachusetts Institute of Technology

Syracuse University

Urban Institute 


\begin{abstract}
This paper describes contributions to employer-sponsored retirement accounts, using newly available longitudinal data that combine administrative earnings records with survey data. The results reveal a fair amount of individual variability in contribution rates over time. However, potential negative shocks to income and increases in current consumption needs do not appear to lead workers to curtail their contributions. Instead, workers appear to raise their contribution rates after they have achieved key milestones in the lifecourse, such as the birth of a child or the purchase of a home.
\end{abstract}




\section{INTRODUCTION}

As defined contribution plans have come to dominate the pension landscape, retirement income security increasingly depends on the ability and willingness of families to defer current consumption and save for their old age. In earlier generations, when traditional defined benefit plans were commonplace, many older people could rely on their employers to save on their behalf. Defined benefit plan participants have little say over the size of their pension benefits, which generally depend only on earnings and years of service. Typical defined benefit plans automatically enroll all eligible workers and rarely require explicit contributions from participants. Workers at firms that offer defined contribution plans, by contrast, must decide whether to participate in the plan, and participants much choose how much to set aside from each paycheck and invest in their retirement accounts. Future benefits depend on the level of contributions from participants and their employers and the returns that the contributions earn. Families must generally set aside funds over many years to accumulate significant retirement savings in their defined contribution plans.

However, families may be forced to delay or interrupt their retirement savings for a variety of reasons. For example, families may delay saving for retirement until after they purchase homes, focusing their efforts on accumulating enough savings for a downpayment before worrying about retirement. The expenses associated with a new baby may lead families to interrupt their retirement contributions near the birth of a child, especially if one parent spends less time at work in order to provide childcare. The loss of a spouse, through death or divorce, or a spell of unemployment by a spouse can also lead workers to curtail their retirement contributions and spend more of their earnings on current consumption. In addition, the onset of health problems for the worker or family members can derail savings plans, either because the 
family must pay expensive medical bills or because poor health forces family members to curtail their labor supply, lowering family income. In short, any increase in current consumption needs or loss of current income can reduce contributions to retirement plans and threaten future retirement security.

This study uses newly available longitudinal data to describe contributions to employersponsored retirement plans over time for a large, nationally representative sample of workers. The analysis examines the share and characteristics of workers who contribute to retirement plans and the level of their contributions. It describes the patterns of plan contributions over time and how spouses coordinate their contributions. The analysis also shows how key lifecourse events, such as the birth of a child, changes in marital status, and the purchase of a home, affect the level of participation in defined contribution plans.

The results confirm many significant relationships found in other research. For example, we find that about one-quarter of all workers contribute to employer-sponsored tax-deferred retirement accounts, and that the median contribution rate is about 6 percent of earnings. We also find that participation rates and contributions increase with age, education, and earnings. Contrary to other research, our results reveal a fair amount of individual variability in contribution rates over time, but negative shocks to income and increases in current consumption needs do not appear to lead workers to curtail their contributions. Instead, workers appear to raise their contribution rates after they have achieved key milestones in the lifecourse, such as the birth of a child or the purchase of a home.

\section{BACKGROUND}

The share of workers with pension coverage on the current job has remained fairly steady over the past 20 years, at about 45 percent (Copeland 2002), but the type of coverage has 
changed dramatically. Participation in defined benefit pension plans, long the most common type of retirement plan, has eroded over time, while defined contribution plans have become dominant. From 1980 to 1998 , the share of covered private wage and salary workers with a primary defined contribution plan increased from 17 percent to 56 percent (U.S. Pension and Welfare Benefits Administration 2001-2002). During the same period, the share of private pension assets in defined contribution plans increased from 29 percent to 52 percent. $^{1}$

Defined contribution plans, which include 401(k) plans, deferred profit sharing plans, and employee stock ownership plans, function essentially as tax-advantaged retirement savings accounts. Unlike traditional defined benefit plans, they do not promise to pay any particular benefit at retirement. Instead, participants in most defined contribution plans contribute to retirement accounts, which they hold in their own names and generally invest in equities, mutual funds, bonds, cash, and guaranteed investment contracts. At retirement, participants receive benefits equal to the balances that have accumulated in their accounts. In salary reduction plans such as 401(k) plans, which are now the most common type of defined contribution plan, participants defer federal and state personal income taxes on their contributions, up to certain limits. (In 2004, participants may defer taxes on contributions up to $\$ 13,000$.) Employers also generally make contributions to their workers' retirement accounts. In some plans, employer contributions depend on how much the participant contributes, and some employers contribute only if the participant contributes. In other plans, employers do not contribute at all even when participants contribute.

\footnotetext{
${ }^{1}$ Defined benefit plans have also experienced significant change in recent years. Many large employers that offer defined benefit plans have converted to cash balance and other types of hybrid plans that include features characteristic of defined contribution plans, even though they continue to be classified as defined benefit plans (Johnson and Uccello 2004). Thus, the movement away from traditional pension plans to defined contribution formats is even more pronounced than these statistics suggest.
} 


\section{Participation and Contribution Rates in Defined Contribution Plans}

Participation in 401(k) plans is voluntary, and few eligible workers make the most of their plans. About one-quarter of eligible participants opt out completely (Copeland and VanDerhei 2000), and only 8 percent of participants contribute the maximum (Munnell and Sundén 2004). Among those who work for employers that offer defined contribution retirement plans and who qualify to participate, participation rates increase with earnings, income, education, and age (Andrews 1992; Bassett, Fleming, and Rodrigues 1998; Hinz and Turner 1998; Kusko, Poterba, and Wilcox 1998; Muller forthcoming; Munnell, Sundén, and Taylor 2003). ${ }^{2}$ Participation rates are also higher in plans in which employers match at least part of the contributions made by workers than in plans in which employer contributions do not depend on whether the worker contributes (Basset et al. 1998; Clark, Goodfellow, Schieber, and Warwick 2000; Clark and Schieber 1998; Muller forthcoming; Papke, Petersen, and Poterba 1996). Workers are also more likely to participate when they can borrow from their funds (Munnell, Sundén, and Taylor 2003).

Most studies have found that employee contributions to employer-sponsored retirement plans and contribution rates increase with earnings, income, and age (Andrews 1992; Clark et al. 2000; Clark and Schieber 1998; Holden and VanDerhei 2001). ${ }^{3}$ The evidence on the impact of employer match rates on contribution rates is mixed. Clark and Schieber (1998) found that employer match rates significantly increase participant contribution rates, but Andrews (1992) and Munnell et al. (2003) found that they depress participant contribution rates, possibly because

\footnotetext{
${ }^{2}$ Muller (forthcoming) finds that the likelihood of participating increases until age 50, and then begins to decline. ${ }^{3}$ However, Andrews (1992) found that earnings has no effect on contribution rates, and Clark et al. (2000) found that contribution rates decline with earnings for workers with very high salaries.
} 
many workers establish savings targets. When their employers contribute generously to their retirement accounts, they can reduce their own contributions and still reach their savings goals. Most of the existing literature on retirement plans uses cross-sectional data. The few studies that use longitudinal data find that participation and contribution rates are fairly stable over time. For example, Kusko, Poterba, and Wilcox (1998) examined administrative plan data provided by Buck Consultants that tracked employees at a single large firm from 1988 to 1991. They found that most workers maintained the same contribution rate year after year, despite changes in the employer match rate.

Other studies have also found that relatively few people change their retirement savings behavior from one period to the next. For example, in one survey of employees at a large U.S. firm, 35 percent said they were saving too little in their retirement plans and intended to increase their contribution rates in the next few months (Choi, Laibson, Madrian and Metrick 2002). (No one in the survey expressed any plans to lower his or her contribution rate.) However, when the researchers re-interviewed these workers four month later, only 14 percent of the "under-savers" had actually increased their contribution rates. Madrian and Shea (2001) and Papke, Peterson, and Poterba (1996) also found a great deal of stability in participation and contribution rates among workers offered 401(k) plans.

Evidence also exists suggesting persistence in participation in Individual Retirement Accounts (IRAs). Skinner (1992), using a sample of tax returns for the period 1982 to 1986, found strong persistence in IRA contributions among those who first contributed to IRAs at the beginning of the period. Smith (2001) found somewhat less persistence in a panel of individual tax returns from 1987 to 1996, but most of the drop off in those making contributions in his sample occurred in the first four years after the initial contribution to the IRA. Only 45 percent 
of eligible taxpayers contributed in 1992, among those who contributed in 1987. However, 40 percent continued to contribute through 1996.

Many of these longitudinal studies use administrative data, either from plan providers or from tax records. They probably provide more accurate information than the many crosssectional studies based on surveys that collect self-reports of participation and contributions, because most workers are not well-informed about their retirement plans (Johnson, Sambamoorthi, and Crystal 2000; Mitchell 1988). ${ }^{4}$ However, few administrative data sets include much information about participant characteristics. They generally lack data, for instance, on participants' marital status, health status, non-employment income, assets held outside of the retirement plan, home purchases, or the characteristics of the spouse. And plan data generally include no information about employees who do not participate. As a result, little is known about how key demographic and economic shocks that can occur over the lifecourse affect participation in retirement plans and the amounts that participants contribute.

\section{Potential Disruptions to Retirement Savings}

Economic theory maintains that people save in order to smooth consumption over time. The standard models predict that people defer current consumption and set money aside for the future so as to equalize the marginal utility of consumption in the present period with the expected marginal utility in future periods. This equilibrium condition implies that an unexpected increase in current consumption needs or an unexpected decline in current income will induce people to reduce savings, perhaps in part by lowering their contributions to employer-sponsored retirement plans. Possible examples of these shocks include the loss of a

\footnotetext{
${ }^{4}$ A few cross-sectional studies have also used administrative data. These include Holden and VanDerhei (2001), which used data from plan providers, and Joulfaian and Richardson (2001), which used tax data to measure worker contributions to employer-sponsored retirement plans and IRAs.
} 
spouse (due to death or divorce), the onset of health problems for a family member or oneself, and a spell of unemployment. Of course, the impact on retirement contributions may be insignificant if people are able to anticipate these events and plan accordingly.

Key lifecourse events, such as the birth of a child or the purchase of a home, can also lead people to reduce retirement contributions. But workers might choose to maintain their plan contributions and instead increase current spending by borrowing from their 401(k) plans, especially if the shock to income or consumption needs is temporary. Many plans allow workers to borrow from their retirement accounts. The most common reason for loans is to purchase a home or make home improvements or repairs (Munnell and Sundén 2004). ${ }^{5}$

\section{METHODS}

We examine contributions to employer-sponsored retirement plans over time and how they interact with key lifecourse events for a large sample of workers. The data come from the 1996 Survey of Income and Program Participation (SIPP), linked to administrative data from the Social Security Administration (SSA)'s Detailed Earnings Record. The SIPP data provide rich demographic, social, and economic information for a nationally representative sample of more than 36,000 households. The 1996 SIPP panel interviewed all household members ages 15 and older every four months, from 1996 until 2000/2001. The survey collected basic demographic data, including age, race, gender, marital status, and education, as well as information about employment status, income, and earnings.

Special topical modules in the SIPP survey provide additional information on marital histories, fertility histories, employment histories, disability, asset holdings, and employersponsored pension participation. In particular, the survey asked respondents with work

\footnotetext{
${ }^{5}$ In 2001, 16 percent of 401(k) participants eligible to borrow had an outstanding loan, and the average loan balance amounted to 14 percent of the account balance net of the unpaid loan (Holden and VanDerhei 2003).
} 
limitations about when their health problems started, and asked homeowners about when they purchased their homes. Thus, the data allow us to identify the timing of key lifecourse events, including marriages, divorces, widowhood, the birth of a child, the onset of health problems that limit the ability to work, and the purchase of a home. ${ }^{6}$ Because the survey interviewed all adult members of the household, it also provides information about key transitions in the spouse's life. $^{7}$

The Detailed Earnings Record contains information collected from the Internal Revenue Service's Form W-2, which employers must file to report salaries and benefits they pay to their employees. ${ }^{8}$ For those individuals in the SIPP who allowed their responses to be matched to Social Security Administration data, the dataset provides annual information on total earnings, earnings covered by Social Security, taxable earnings, and tax-deferred contributions to employer-sponsored retirement accounts from 1990 to $2001 .{ }^{9,} 10$ The earnings file also includes an employer identification code, identifying those who change jobs over time.

We use the contemporaneous and retrospective SIPP data in combination with the earnings file to create a longitudinal sample extending from 1990 to 2001. For each year, our sample includes measures of total pre-tax earnings; the level of contributions to employersponsored retirement plans; contributions as a share of pre-tax earnings; earnings and retirement contributions for the spouse; the respondent's age, gender, race, education, and marital status; the

\footnotetext{
${ }^{6}$ Because the survey asked only about the date of purchase of the current home in 1997, we cannot identify previous home purchases.

${ }^{7}$ Information is not available about the characteristics of former spouses from marriages that ended before the baseline 1996 survey, however.

${ }^{8}$ Because of privacy concerns, only researchers who obtain special permission from SSA can access the Detailed Earnings Record, and they can only be analyzed at secure computing facilities at SSA offices. The data are reported separately for self-employed and for wage and salary employees.

${ }^{9}$ Information on retirement plan contributions correspond to codes $d$ through $\mathrm{h}$ in box 13 on the W-2 form: $401(\mathrm{k})$, SIMPLE, 403(b), 408(k)(6), SEP, 457(b), and 501(c)(18)(D) plans.
} 
presence of any work limitations for the respondent or spouse; home ownership; and indicators of a change in marital status, the onset of work limitations (for the respondent or spouse), the purchase date of a home, and the loss of spousal income. All dollar amounts are expressed in constant 2004 dollars (indexed to changes in the Consumer Price Index).

An important limitation of our dataset is that it does not provide reliable information about defined contribution plan offers before 1997. The survey asked respondents in 1997 whether their employers offered defined contribution retirement plans and whether they were eligible to participate, but it did not ask about when the employer first began offering the plan. The survey did ask respondents about the number of years they have spent working for the employer (and the earnings file also provides employer identification codes that allow us to identify job changes), but some employers who offered plans in 1997 may not have offered them in 1990, especially given the growth in 401(k) plans that occurred during the 1990s. Thus, we cannot realistically assume that workers whose employers offered 401(k) plans in 1997 had access to them from the time they joined their employers. As a result, we cannot measure participation rates before 1997 conditional on eligibility (although we do construct this measure for 1997).

In addition, some measures that are likely to be associated with retirement plan contributions are not available before 1996, because the survey did not collect retrospective data on many topics. These unavailable measures include total family income, assets, and employer match rates.

\footnotetext{
${ }^{10}$ We restrict the sample to SIPP wave 7 respondents with a match on the Detailed Earnings Record. About 16 percent of wave 7 respondents do not have a match on the Detailed Earnings Record, primarily because they refused to report their Social Security numbers.
} 
We restrict the sample to workers ages 20 to 69 who report positive earnings in the given year. We exclude workers younger than 20 because many employers do not allow them to participate in retirement plans, and we exclude workers older than 69 because people must begin withdrawing funds from defined contribution plans at age 69-and-a-half. Our sample includes 373,971 observations between 1990 and 2001 on 65,430 individuals, 31,825 of whom had earnings in 1997.

We begin by tabulating participation rates, contribution levels, and contributions by year, age, gender, race, marital status, educational attainment, and earnings level. We also examine the correlation of contributions between husbands and wives. Next, we examine contribution patterns over time. Finally, we estimate logit models of the participation decision and linear regression models of the level of contributions, for workers contributing to their retirement plans. Predictors in the model include age and its square (to capture nonlinear effects of age), marital status, earnings, the number of children under age 18, the presence of a work limitation, the presence of a working spouse, and indicators (during the current year) of the onset of work limitations, the purchase of a home, the birth of a child, the death of a spouse, the dissolution of a marriage through divorce, and measures of unemployment and job change. We also experiment with lagging these indicators, to explore whether the impact on retirement contributions persists a few years after the event.

\section{RESULTS}

\section{Participation in Defined Contribution Retirement Plans}

About 27 percent of workers between the ages of 20 and 69 contributed to a tax-deferred employer-sponsored retirement plan between 1990 and 2001 (see table 1). Participation rates increased over the period, as more employers began offering these types of plans to their workers 
and as workers became more familiar with them. Between 1990 and 2001, the share of workers contributing to defined contribution retirement plans doubled, rising from 17 percent to 34 percent. In every year, the participation rate increased with age until workers reached their mid50 s, and then fell at older ages (see figures 1 and 2). ${ }^{11}$

Participation rates also increased with both individual and family earnings (see figure 3). Interestingly, participation rates rose monotonically with family earnings, but they fell with own earnings once earnings levels exceeded $\$ 130,000$ per year. This difference may be due to federal nondiscrimination rules that limit participation in retirement plans by highly compensated employees or by differences in the likelihood of participation between wage and salary workers and self-employed workers (since many of the high earners are self-employed). This surprising finding merits further exploration.

Although figure 1 reports participation rates for all workers, many employers do not offer tax-deferred plans to their employees. As noted earlier, SIPP did not collect retrospective information on employer plan offers, but it did collect data on plan offers in 1997. Only about 42 percent of workers were offered retirement plans by their employers in 1997 (see appendix table A2). When we restrict our sample to workers whose employers offered retirement plans, participation rates in 1997 rise from 30 percent to 72 percent (see figure 4). Conditioning the sample on the receipt of offers does not substantially change the patterns of participation. As we found in the full sample of workers, participation among workers with offers increased with age through about age 55 and then fell. Differences in participation rates between the full sample and the sample of workers with plan offers were greater for younger and older workers than for those ages 30 to 59. This finding implies that one reason for the low participation rate among young workers is that they tend to work in jobs that are less likely to offer retirement plans (see

\footnotetext{
${ }^{11}$ More detailed results are available in the appendix tables.
} 
figure 5). Similarly, we find that workers with low earnings are less likely to receive plan offers from their employers than better-paid workers, explaining part of the difference in retirement plan participation by earnings (see figure 6). However, participation rates among workers with offers also increase with earnings.

Among workers offered tax-deferred retirement plans, participation rates were similar for men and women, but differed along other demographic characteristics (see table 2). For example, participation rates were higher for married workers than single workers and increased with education. They were also higher for non-Hispanic whites than for blacks or Hispanics.

\section{Contribution Levels and Rates}

Over the period, mean real annual contributions among participants in employersponsored retirement accounts were about $\$ 3,300$ (in 2004 dollars), or 5.4 percent of total earnings (see table 3). The level of real contributions generally increased during the 1990s, rising from an average of about $\$ 3,000$ in 1991 to $\$ 3,600$ in 2001 . The growth in real earnings accounted for part of the increase, but age-specific contribution rates (contribution amount/total earnings) also increased over time for participants younger than age $50 .{ }^{12}$ Interestingly, contribution rates appear to have fallen slightly over time for the oldest workers.

Average real contribution amounts among participants increased with both own and family earnings (see figure 7). Contribution rates did not, however, rise monotonically with earnings - instead, they exhibited more of an S-shaped pattern (see figure 8). The average contribution rate was about 5 percent for participants earning less than $\$ 5,000$ per year. The rate then fell to about 4 percent for participants earning about $\$ 20,000$ per year, increased to about 7 percent for participants earning about $\$ 90,000$ per year, and fell back to about 5 percent for the

\footnotetext{
${ }^{12}$ Contributions in 1990 appear to be unusually high, especially for older workers. This result could reflect start-up problems with the data collection system, and merits further investigation.
} 
highest earners. Contribution limits and nondiscrimination rules prevent high earners from contributing at higher rates. Despite these limits, the highest income group did contribute more on average than any other group of workers. And at all levels of earnings, younger participants tended to contribute a smaller share of their earnings than older participants.

The median contribution rate for participants between 1990 and 2001 was about 6 percent, and it increased with age (see figure 9). About 83 percent of 20- to 29-year-old participants contributed less than 6 percent, compared with only 48 percent of 60 - to 64 -yearolds.

\section{Correlation of Participation Between Husbands and Wives}

One of the key advantages of our data is that they include information on participation and contribution levels for both husbands and wives. Table 4 shows the weighted number of married couples ages 20 to 69 (husband's age) in 1997 by both the husband's and wife's contribution levels. Of the nearly 40 million couples, 56 percent had no family tax-deferred contributions in 1997. Only the husband contributed to a tax-deferred plan in 23 percent of couples, and only the wife contributed in 12 percent of couples. Both spouses contributed in 10 percent of couples.

Generally, the husband's contribution increased with the wife's contribution. Figure 10 shows the distribution of husband's deferred contribution by the wife's contribution in 1997. Among couples in which the wives did not contribute to an employer-sponsored retirement plan, 71 percent of their husbands did not contribute at all and only 8 percent of them made annual contributions of $\$ 5,000$ or more. The share of husbands who did not contribute fell as their wives' contributions increased. For wives contributing $\$ 5,000$ or more, only 42 percent of 
husbands made no deferred contributions, whereas another 42 percent of husbands contributed $\$ 5,000$ or more.

\section{Tracking Individual Participation Rates Over Time}

Another advantage of our data is that they allow us to track deferred contributions between 1990 and 2001 for our sample of workers. Among individuals ages 20 to 69 in 2001, 58 percent did not make any contributions to employer-sponsored tax-deferred retirement plans over the 12-year period (see table 5). Overall, 19 percent of workers contributed in 1 to 4 years during the period, another 17 percent contributed in 5 to 10 years, and 6 percent contributed in 11 to 12 years. The share of individuals with no contributions was especially high at both ends of the age distribution, because both older and younger people were less likely than others to have worked throughout the entire 12-year observation period and to have held jobs that offered defined contribution plans. Between ages 30 and 59, the number of years during the period in which workers participated generally increased with age. But even among workers ages 50 to 59 , only 8 percent participated in every year. Men tended to have more years of participation than women, reflecting their stronger attachment to the labor force, but the differences were small.

\section{Contribution Patterns Over Time}

Next we explore contribution patterns over the 12-year period, that is, the variability of participation and contribution rates over time. We classify participants into the following five mutually exclusive categories:

1. Intermittent-individuals with more than one spell of deferred contributions (that is, those who had at least one complete calendar year with no contributions between years with positive contributions); 
2. Steady - individuals with stable contribution rates (contributions divided by total earnings) over time. Specifically, the annual change in the contribution rate did not exceed one percentage point in any years with positive contributions;

3. Rising - individuals with rising contribution rates over time. Specifically, the annual increase in the contribution rate exceeded one percentage point in at least one year with positive contributions, and the contribution rate never fell by as much as one percentage point;

4. Falling - individuals with falling contribution rates over time. Specifically, the annual decrease in the contribution rate exceeded one percentage point in at least one year with positive contributions, and the contribution rate never increased by as much as one percentage point;

5. Fluctuating —individuals whose contribution rates rose and fell during the period. We restrict the sample to individuals between the ages of 20 and 69 in 2001 who contributed to an employer-sponsored tax-deferred retirement plan at some point between 1990 and 2001.

About 27 percent of our sample made steady contributions and 24 percent had only rising contributions. Nearly half of all contributors had more variable contribution patterns. Nineteen percent had intermittent contributions, 8 percent had falling contribution rates, and 23 percent had fluctuating contributions (see figure 11). The variation in contribution rates is noteworthy, because it calls into question the finding from previous research that individuals rarely change their contribution behavior over time (Choi et al. 2002; Madrian and Shea 2001; Papke, Peterson, and Poterba 1996). Contribution patterns were more stable for younger workers, but they have had fewer years to contribute to plans. 
Not surprisingly, contribution patterns become increasingly variable as the length of the contribution period increases (see figure 12). Among workers with 12 years of deferred contributions, for example, 53 percent had fluctuating contribution rates, compared with just 26 percent among those with 5 to 7 years of contributions. Although much of the rise in fluctuations with years of contributions may be due simply to increased exposure, contribution limits may also play a role, as workers' earnings increase over time. In fact, the share of workers with intermittent and fluctuating contributions increases with earnings. For example, the majority of lower-earning workers make steady contributions, compared with only about 5 percent of workers earning between $\$ 100,000$ and $\$ 150,000$ per year (see figure 13).

Contribution limits may cause the contribution rate to decline for high earners as earnings rise, but they should not reduce the amount contributed by highly compensated workers below the statutory cap. We explore whether contribution limits account for fluctuations over time in the contribution rate by re-defining our contribution profiles. Instead of defining our profiles on the basis of a one percentage point change in the contribution rate, we define them using a 10percent change in the nominal contribution amount. Using our alternate definition of contribution profiles, we continue to find that a larger share of high-earning workers exhibit fluctuating contribution patterns than low-earning workers. This result implies that contributions fluctuate independent of the contribution limits. About 22 percent of high earners (with average earnings of $\$ 60,000$ or more per year) have intermittent contributions.

\section{Multivariate Estimates of Participation and Contributions}

Table 6 reports logistic regression coefficient estimates for plan participation for workers offered employer-sponsored tax-deferred retirement plans in 1997. The most important predictor of participation was own earnings. As income rises, families are able to save more of their 
earnings, and the tax advantages of saving in tax-deferred vehicles increase. Age is also important. The probability of participating increased with age, but at a decreasing rate. Controlling for earnings and other characteristics, married couples were less likely to participate than single individuals, especially when both spouses were employed, but the probability of participating increased the more the worker's spouse contributed. This result implies that couples share retirement saving goals, with both partners tending to contribute together. Having a defined benefit plan in addition to a defined contribution plan increased the worker's probability of participating in the defined contribution plan. Owning a home increased the probability of participating in a tax-deferred plan, but (contrary to our expectations) workers did not halt plan contributions in the period before they purchased their home. Changes in marital status do not appear to alter workers' participation decisions: None of the marital status change variables were significant. Participation rates declined slightly with the number of children under age 18, but the birth of a child in the current or previous year increased participation rates. The presence of health problems that limit work did not have a significant impact on participation for the worker, but having a spouse with health problems increased the probability of contributing to a retirement plan. ${ }^{13}$ Changing jobs and returning to work after a period of no employment (zero earnings for at least one calendar year) significantly reduced the probability that the worker contributed, probably because many employers impose minimum tenure requirements on new employees before they can participate in the plan. In addition, the probability of participating increased when the spouse changed jobs or returned to work, perhaps because these transitions increased family income. We found that the probability of participation was greater for workers who could borrow from their plans than for those who could not borrow,

\footnotetext{
${ }^{13}$ The sample is restricted to working individuals offered a plan. This implies that any reported work limitations were not severe enough to prevent the respondent from remaining employed.
} 
but the probability of participation fell when the employer contributed to the plan. This result suggests that many workers may have particular savings targets, and that they choose to divert less of their current income to savings when their employers save on their behalf.

Table 7 reports results from our OLS regression of tax-deferred retirement contributions for participating workers. Holding other factors constant, contributions increased with earnings and age (after about age 33). Having a spouse who contributed to a deferred plan lowered contribution amounts, but own contributions increased when the spouse began making contributions and as the spouse's contributions rose. Own contributions were higher in the year after a spell of unemployment for both the worker and the spouse, perhaps because workers strive to catch-up on their retirement savings after a period with no earnings (and presumably no savings). Contributions decreased, however, after workers changed jobs, but they increased after their spouses changed jobs. Own and spouse work limitations did not significantly affect contribution levels. Contributions fell slightly with the number of children under age 18, but did not change significantly around the birth of a child. Changes in marital status did not significantly impact contribution amounts. Homeowners contributed more on average than renters, but contribution amounts declined slightly in the year of the home purchase. Neither employer contributions nor the ability to borrow from the retirement plan significantly affected the level of plan contributions.

\section{CONCLUSIONS}

Our exploratory analysis of SIPP data matched to the Detailed Earnings Record indicates that this newly available dataset provides a useful source of information on the dynamics of retirement plan contributions. Many of our results confirm findings from earlier studies. For example, we find that about one-quarter of all workers contribute to employer-sponsored tax- 
deferred retirement accounts, and that the average contribution rate is about 6 percent of earnings. We also find that participation rates and contributions increase with age, education, and earnings, consistent with well-established results from previous work.

The data also reveal a few surprising patterns. In particular, we find that contribution rates fluctuated quite a bit over time. Among workers who ever contributed to tax-deferred plans through their employers between 1990 and 2001, only 27 percent contributed roughly the same share of earnings every year. And among those who contributed in all 12 years, 53 percent exhibited fluctuating contribution rates. These findings call into question the commonly held belief that retirement plan participants passively accept default options and rarely adjust their retirement plan contributions.

Workers appear to revise their retirement contributions as they progress over the lifecourse. Many increase their contribution rates after they have achieved key milestones, such as the birth of a child or the purchase of a home. With these experiences under their belts, they may be better able (psychologically or financially) to begin preparations for retirement. The results also show that participation rates and contribution amounts decreased after job changes, reflecting the fact that many employers do not allow new workers to participate in their retirement plans until they have spent at least one year on the job. A spell of unemployment reduced the probability of participation, but increased contribution amounts among those who did participate after they were re-employed. It appears, then, that many unemployed people try to "catch up" in their retirement savings when they resume work. We found little evidence, however, that other potential negative shocks to income or increases in current consumption needs - such as the onset of health problems or the loss of a spouse - lead workers to curtail their retirement plan contributions. But workers could react to these financial pressures by 
borrowing money from their 401(k) plans or taking lump-sum distributions, which might threaten retirement security even if they maintain their plan contributions.

With the erosion of traditional defined benefit pension plans and the growth in defined contribution vehicles, sound retirement planning increasingly depends on the commitment of individuals to invest in tax-deferred retirement accounts throughout their work lives. Our results suggest that relatively few workers take full advantage of the retirement savings options available to them. Participation rates in employer-sponsored tax-deferred retirement plans are low at younger ages, and contributions fluctuate over time. Policies that encourage higher participation and contribution levels throughout workers' careers could significantly enhance retirement security. 


\section{REFERENCES}

Andrews, Emily S. "The Growth and Distribution of 401(k) Plans." In Trends in Pensions, edited by John A. Turner and Daniel J. Beller, 149-176. Washington, D.C.: United States Department of Labor, Pension and Welfare Benefits Administration, 1992.

Bassett, William F., Michael J. Fleming, and Anthony P. Rodrigues. "How Workers Use 401(k) Plans: The Participation, Contribution, and Withdrawal Decisions." National Tax Journal 51 No. 2 (July, 1998): 263-89.

Choi, James J., David Laibson, Brigitte C. Madrian, and Andrew Metrick. "Defined Contribution Pensions: Plan Rules, Participant Choices, and the Path of Least Resistance." In Tax Policy and the Economy, edited by James M. Poterba. Cambridge, Ma.: MIT Press, 2002.

Clark, Robert L., Gordon P. Goodfellow, Sylvester J. Schieber, and Drew Warwick. "Making the Most of 401(k) Plans: Who's Choosing What and Why?" In Forecasting Retirement Needs and Retirement Wealth, edited by Olivia S. Mitchell, P. Brett Hammond, and Anna M. Rappaport, 95-138. Philadelphia, Pennsylvania: Pension Research Council, the Wharton School of the University of Pennsylvania, and the University of Pennsylvania Press, 2000.

Clark, Robert L., and Sylvester J. Schieber. "Factors Affecting Participation Rates and Contribution Levels in 401(k) Plans." In Living with Defined Contribution Pensions: Remaking Responsibility for Retirement, edited by Olivia S. Mitchell and Sylvester J. Schieber, 69-97. Philadelphia, Pennsylvania: Pension Research Council, the Wharton School of the University of Pennsylvania, and the University of Pennsylvania Press, 1998.

Copeland, Craig. "An Analysis of the Retirement and Pension Plan Coverage Topical Module of SIPP.” EBRI Issue Brief No. 245. Washington, D.C.: Employee Benefit Research Institute, 2002.

Copeland, Craig, and Jack VanDerhei. "Personal Account Retirement Plans: An Analysis of the Survey of Consumer Finances.” EBRI Issue Brief Number 223. Washington, DC: Employee Benefit Research Institute, 2000.

Hinz, Richard P., and John A. Turner. "Pension Coverage Initiatives: Why Don't Workers Participate?" In Living with Defined Contribution Pensions: Remaking Responsibility for Retirement, edited by Olivia S. Mitchell and Sylvester J. Schieber, 17-37. Philadelphia, Pennsylvania: Pension Research Council, the Wharton School of the University of Pennsylvania, and the University of Pennsylvania Press, 1998.

Holden, Sarah and Jack VanDerhei. "Contribution Behavior of 401(k) Plan Participants." Perspective 7 No. 4 (October, 2001): 1-19.

Holden, Sarah and Jack VanDerhei. "401(k) Plan Asset Allocation, Account Balances, and Loan Activity in 2001.” EBRI Issue Brief 255. Washington, D.C.: Employee Benefit Research Institute, 2003.

Johnson, Richard W., Usha Sambamoorthi, and Stephen Crystal. "Pension Wealth at Midlife: Comparing Self-Reports with Provider Data." Review of Income and Wealth 46 No. 1 (March, 2000): 59-83.

Johnson, Richard W., and Cori E. Uccello. "Cash Balance Plans: What Do They Mean for Retirement Security?” National Tax Journal 57 No. 2 (Forthcoming).

Joulfaian, David, and David Richardson. "Who Takes Advantage of Tax-Deferred Savings Programs? Evidence from Federal Income Tax Data." National Tax Journal 54 No. 3 (September, 2001): 669-688. 
Kusko, Andrea L.; James M. Poterba; and David W. Wilcox. "Employee Decisions with Respect to 401(k) Plans." In Living with Defined Contribution Pensions: Remaking Responsibility for Retirement, edited by Olivia S. Mitchell and Sylvester J. Schieber 98-112. Philadelphia, Pennsylvania: Pension Research Council, the Wharton School of the University of Pennsylvania, and the University of Pennsylvania Press, 1998.

Madrian, Brigitte, and Dennis F. Shea. "The Power of Suggestion: Inertia in 401(k) Participation and Savings Behavior." Quarterly Journal of Economics 116 No. 4 (November, 2001): 1149-87.

Mitchell, Olivia S. "Worker Knowledge of Pension Provisions." Journal of Labor Economics 6 No.1 (January, 1988): 21-39.

Muller, Leslie A. "Voluntary Individual Accounts and Social Security Reform: Using 401(k) Participation as a Measure of Individual Account Participation." Social Security Bulletin. (Forthcoming).

Munnell, Alicia H., and Annika Sundén. Coming Up Short: The Challenge of 401(k) Plans. Washington, D.C.: Brookings Institution Press, 2004.

Munnell, Alicia H.; Annika Sundén, and Catherine Taylor. "What Determines 401(k) Participation and Contributions?” Social Security Bulletin 64 No. 3 (January, 2003): 64-75.

Papke, Leslie E. 1995. "Participation in and Contributions to 401(k) Pension Plans: Evidence from Plan Data." Journal of Human Resources 30 No. 2 (Spring, 1995): 311-325.

Papke, Leslie E., Mitchell Peterson, and James M. Poterba. "Do 401(k) Plans Replace Other Employer-Provided Pensions?" In Advances in the Economics of Aging, edited by David A. Wise, 219-236. Chicago: University of Chicago Press, 1996.

Skinner, Jonathan. "Individual Retirement Accounts: A Review of the Evidence." Tax Notes 52 No. 2 (January, 1992): 201-212.

Smith, Paul A. "A Longer-Term Perspective on IRA Participation: Evidence from a Panel of Tax Returns." Office of Tax Analysis, U.S. Department of Treasury, 2001.

U.S. Pension and Welfare Benefits Administration. Private Pension Plan Bulletin: Abstract of 1998 Form 5500 Annual Reports. Washington, D.C.: U.S. Department of Labor, 20012002. 
Figure 1. Participation Rates for Workers by Age and Year, 1990, 1995, and 2001

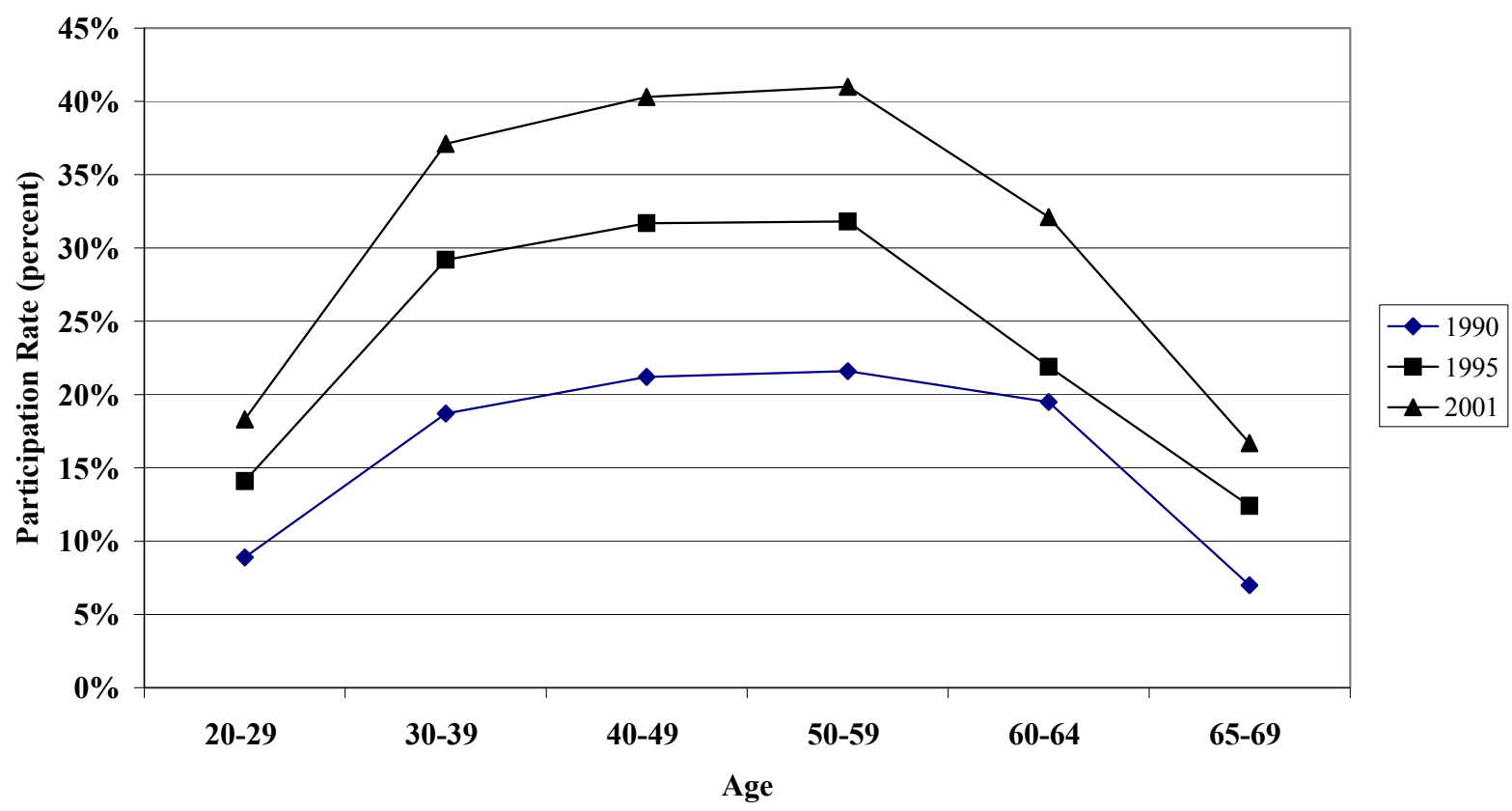

Note: The sample includes all workers ages 20 to 69 , including those not offered defined contribution retirement plans by their employers. There were 29,195 observations in 1990, 31,005 observations in 1995, and 32,964 observations in 2001.

Source: Urban Institute tabulations of the 1996 SIPP matched to the Detailed Earnings Record.

Figure 2. Participation Rates for Workers by Age, 1990 to 2001

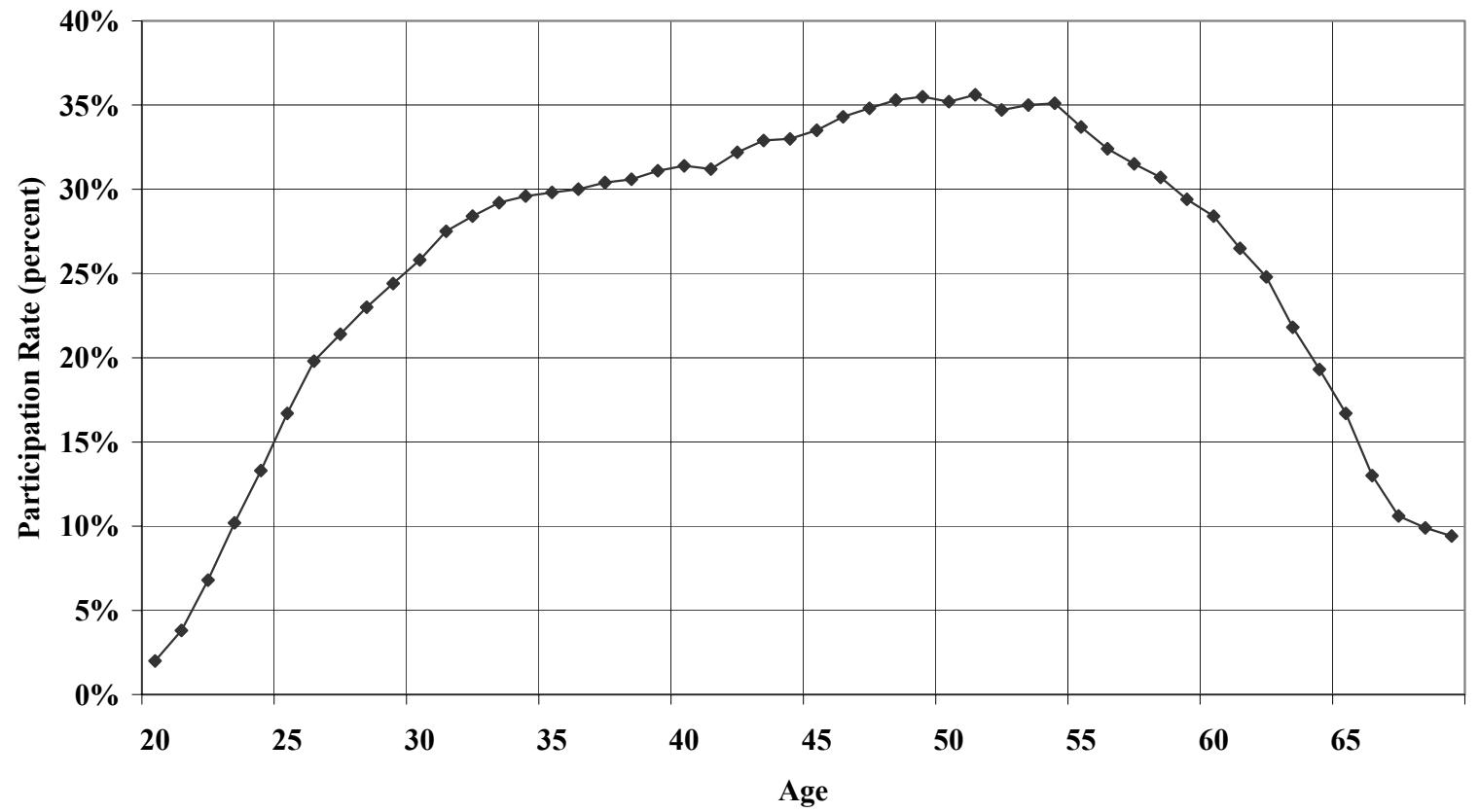

Note: The sample consists of 373,971 observations between 1990 and 2001 on workers ages 20 to 69 , including those not offered defined contribution retiremen plans by their employers.

Source: Urban Institute tabulations of the 1996 SIPP matched to the Detailed Earnings Record. 
Figure 3. Participation Rates for Workers by Own and Family Earnings, 1990 to 2001

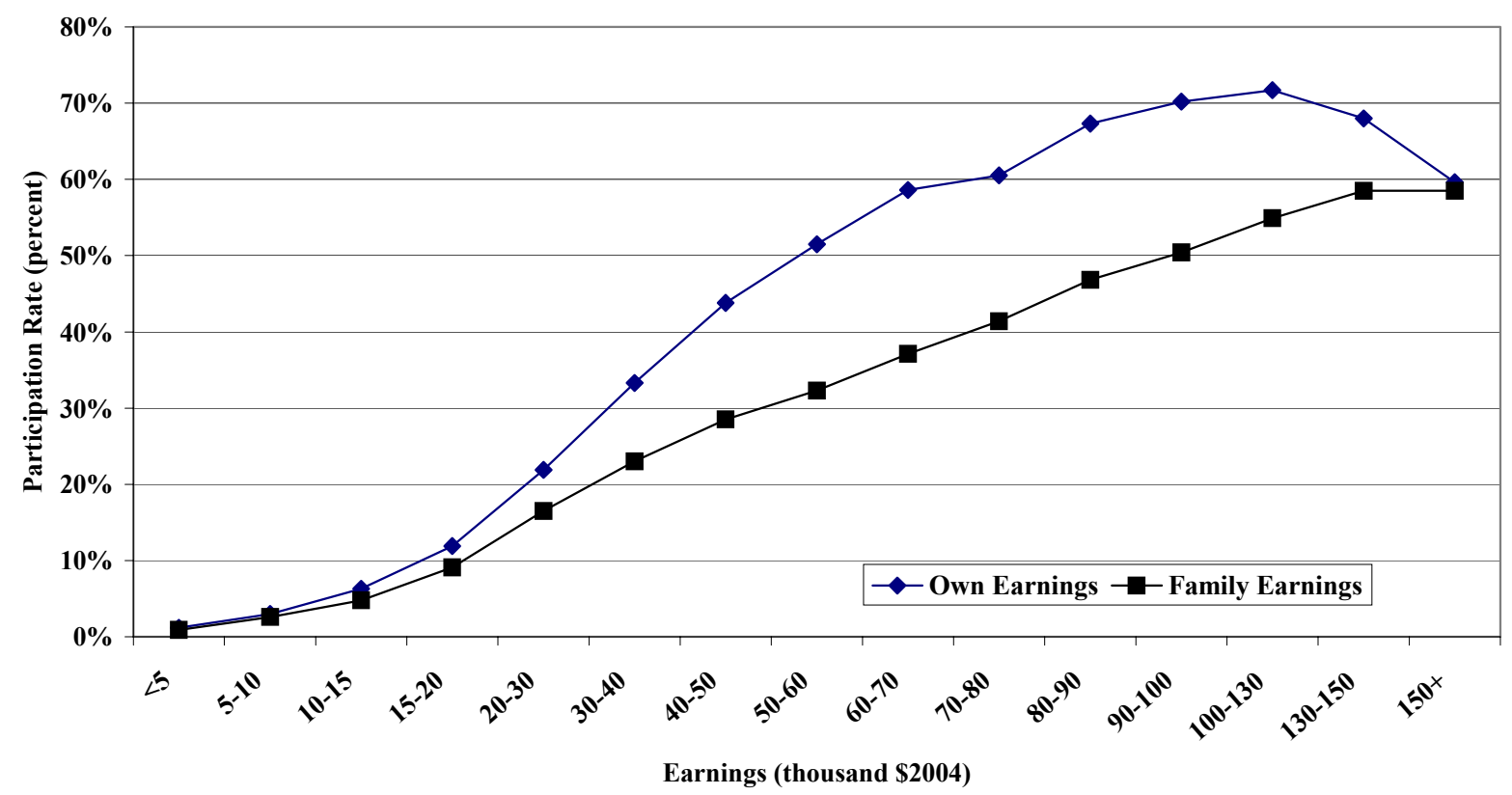

Note: The sample consists of 373,971 observations between 1990 and 2001 on workers ages 20 to 69 , including those not offered defined contribution retirement plans by their employers.

Source: Urban Institute tabulations of the 1996 SIPP matched to the Detailed Earnings Record.

Figure 4. Participation Rates by Age for All Workers and Those with Plan Offers, 1997

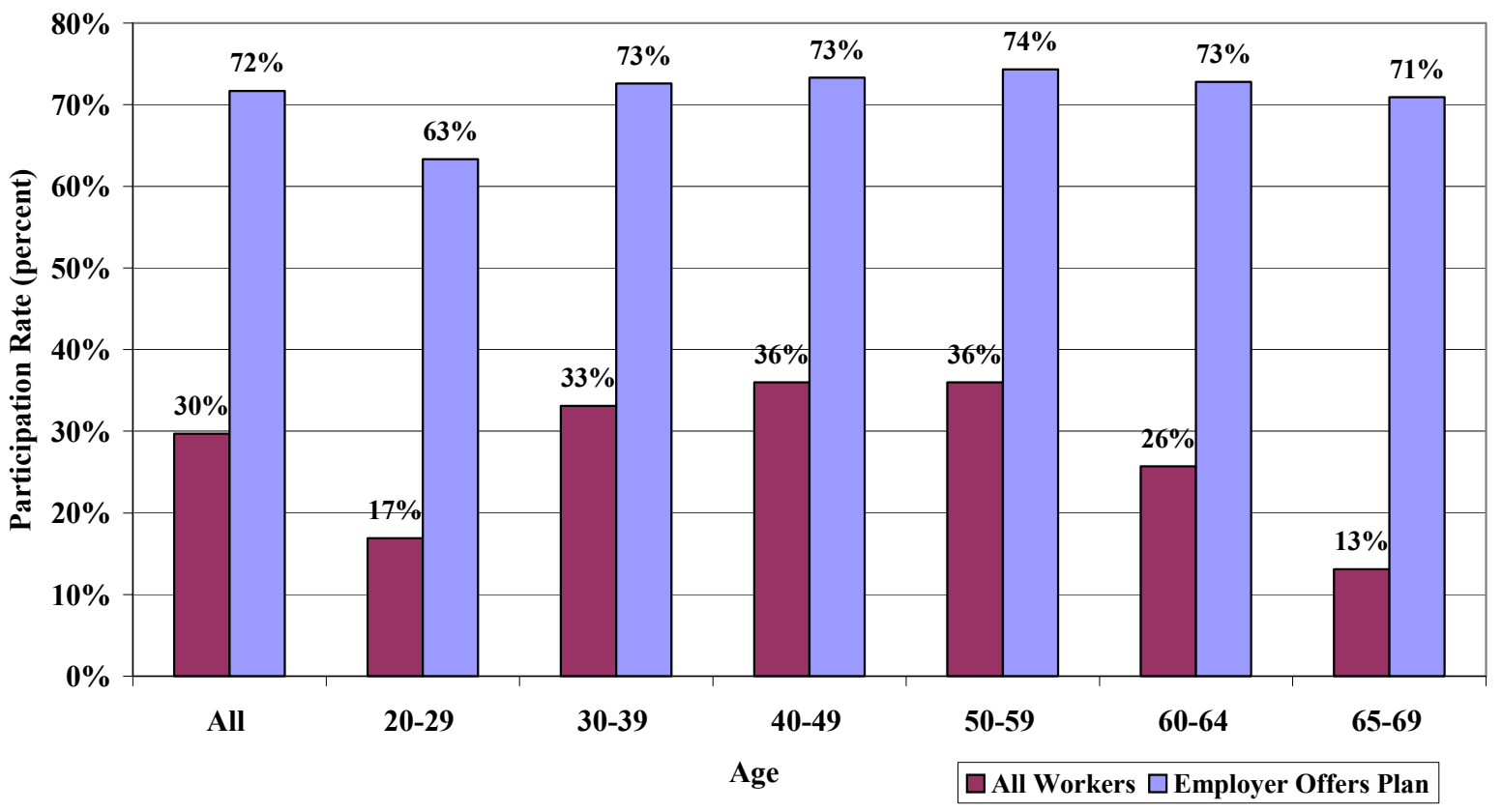

Note: The sample consists of 31,825 workers ages 20 to 69 in 1997, including 13,108 workers whose employers offered them tax-deferred retirement plans. Source: Urban Institute tabulations of the 1996 SIPP matched to the Detailed Earnings Record. 
Figure 5. Share of Workers Offered a Tax-Deferred Retirement Plan and Participation Rates Among Those With Offers, by Age, 1997

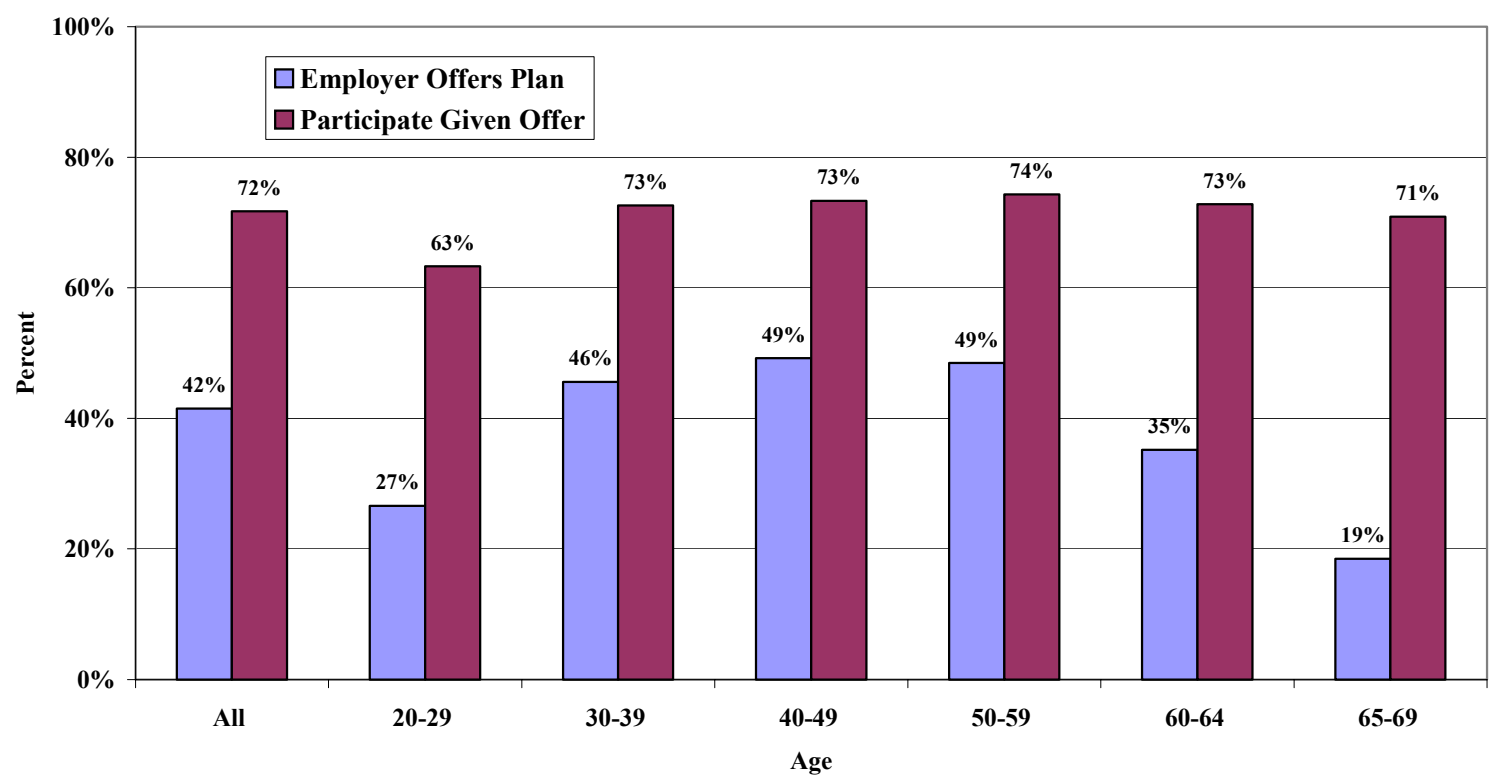

Note: The sample consists of 31,825 workers ages 20 to 69 in 1997, including 13,108 workers whose employers offered them tax-deferred retirement plans.

Source: Urban Institute tabulations of the 1996 SIPP matched to the Detailed Earnings Record.

Figure 6. Share of Workers Offered a Tax-Deferred Retirement Plan and Participation Rates Among Those With Offers, by Earnings, 1997

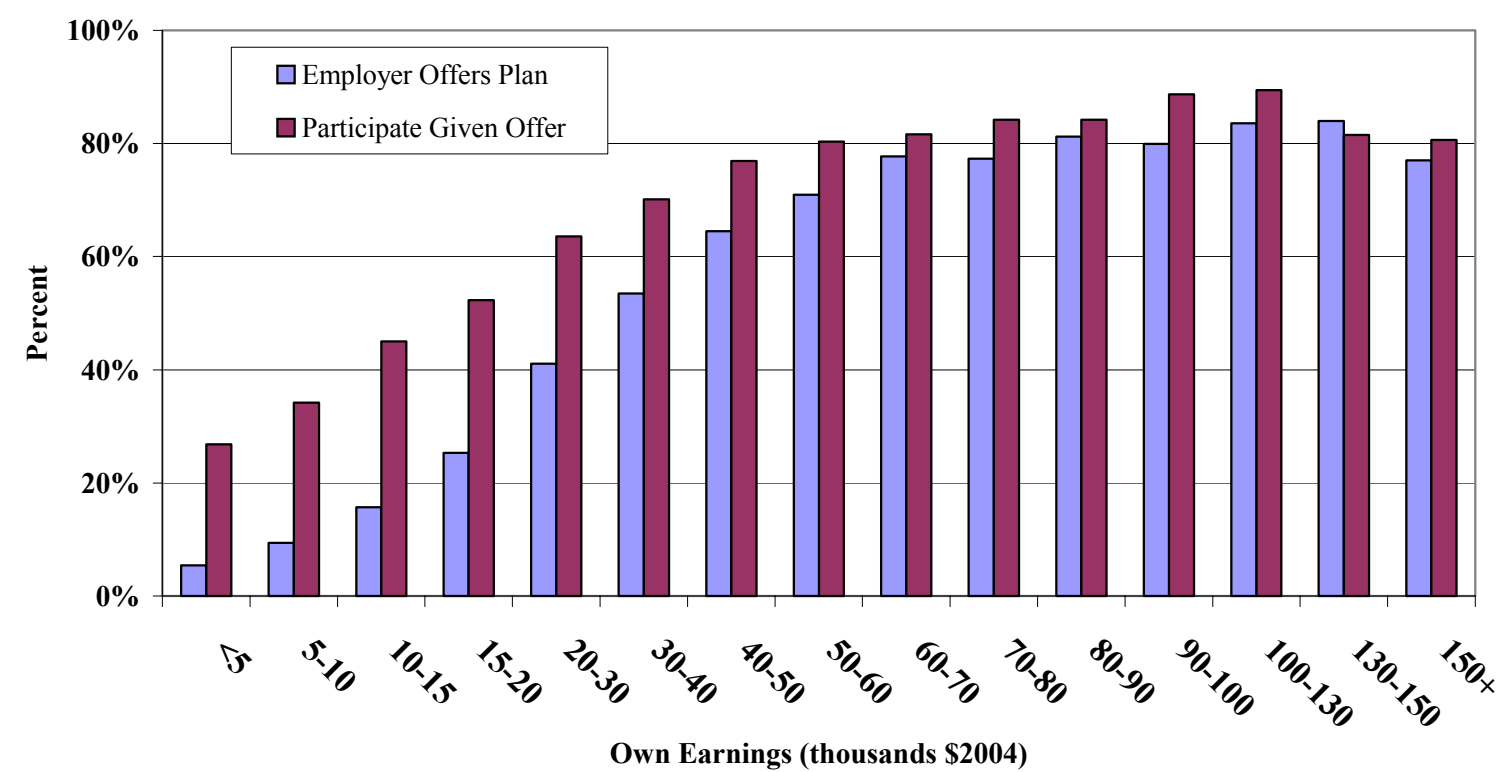

Note: The sample consists of 31,825 workers ages 20 to 69 in 1997, including 13,108 workers whose employers offered them tax-deferred retirement plans. Source: Urban Institute tabulations of the 1996 SIPP matched to the Detailed Earnings Record. 
Figure 7. Average Annual Real Contribution Amounts Among Plan Participants, by Own and Family Real Earnings, 1990 to 2001

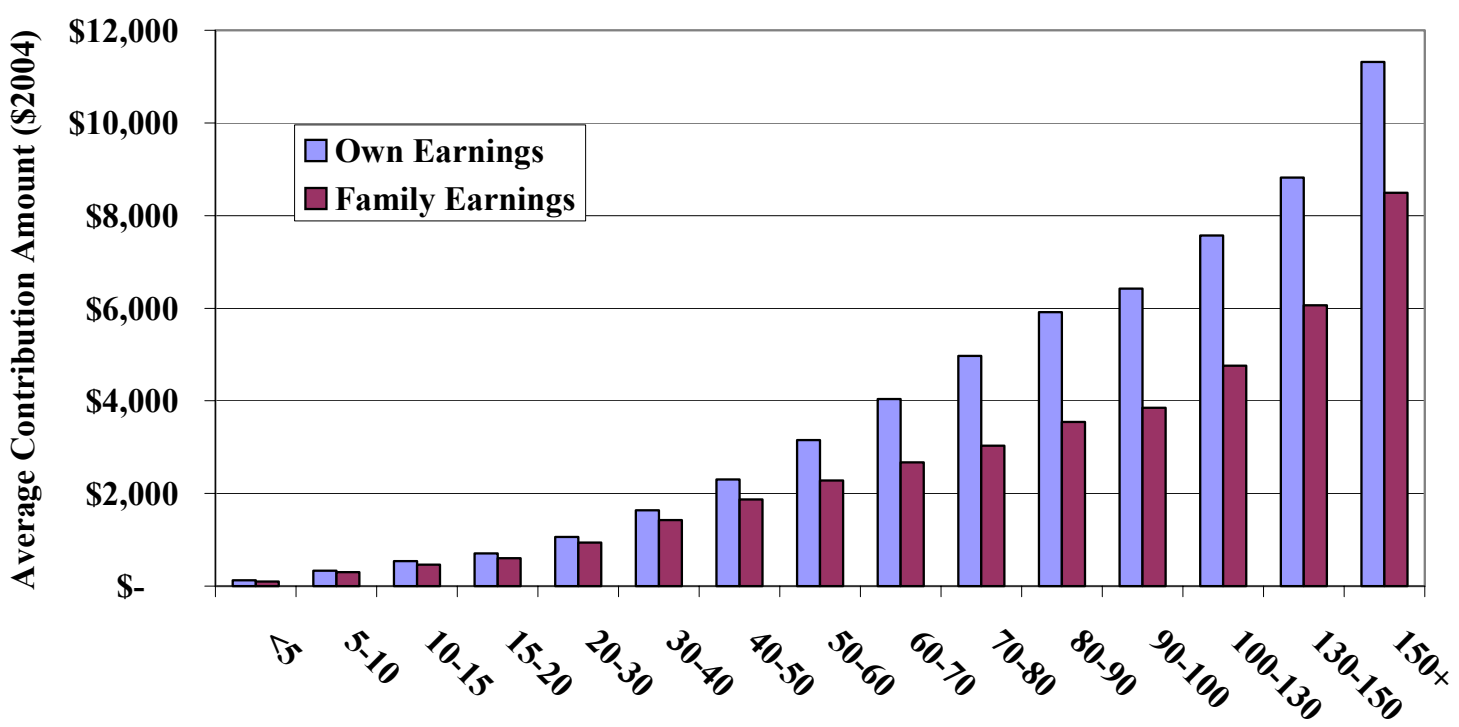

Earnings (thousands \$2004)

Note: The sample consists of 98,734 observations between 1990 and 2001 on workers ages 20 to 69, who contributed to employer-sponsored tax-deferred retirement plans. Annual earnings and contribution amounts are expressed in constant 2004 dollars.

Source: Urban Institute tabulations of the 1996 SIPP matched to the Detailed Earnings Record.

Figure 8. Average Contribution Rates Among Plan Participants, by Own Earnings and Age, 1990 to 2001

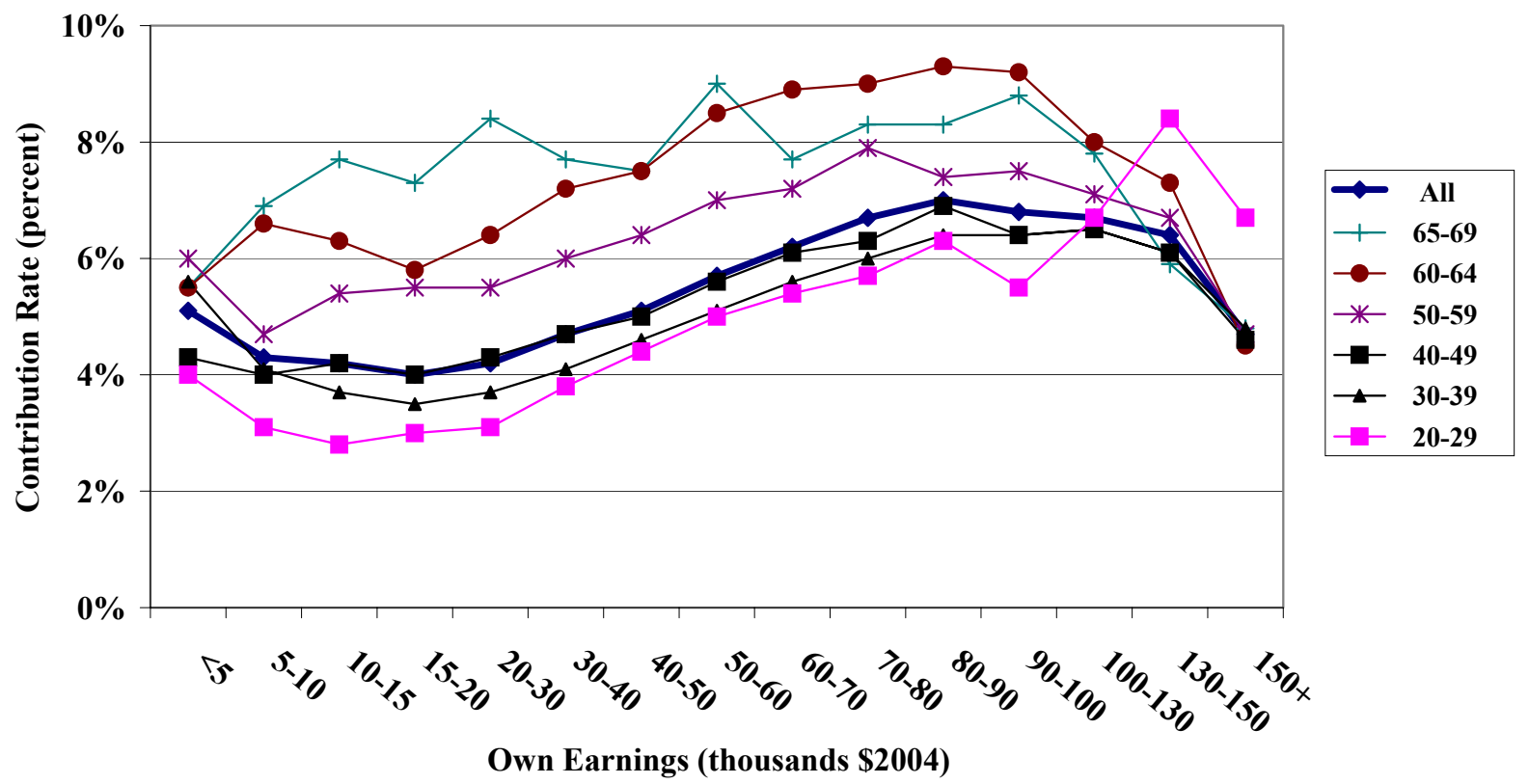

Note: The sample consists of 98,734 observations between 1990 and 2001 on workers ages 20 to 69 , who contributed to employer-sponsored tax-deferred retirement plans. Annual earnings and contribution amounts are expressed in constant 2004 dollars. The contribution rate is defined as the annual contribution amount divided by total annual earnings.

Source: Urban Institute tabulations of the 1996 SIPP matched to the Detailed Earnings Record. 
Figure 9. Distribution of Contribution Rates for Participants by Age, 1990 to 2001

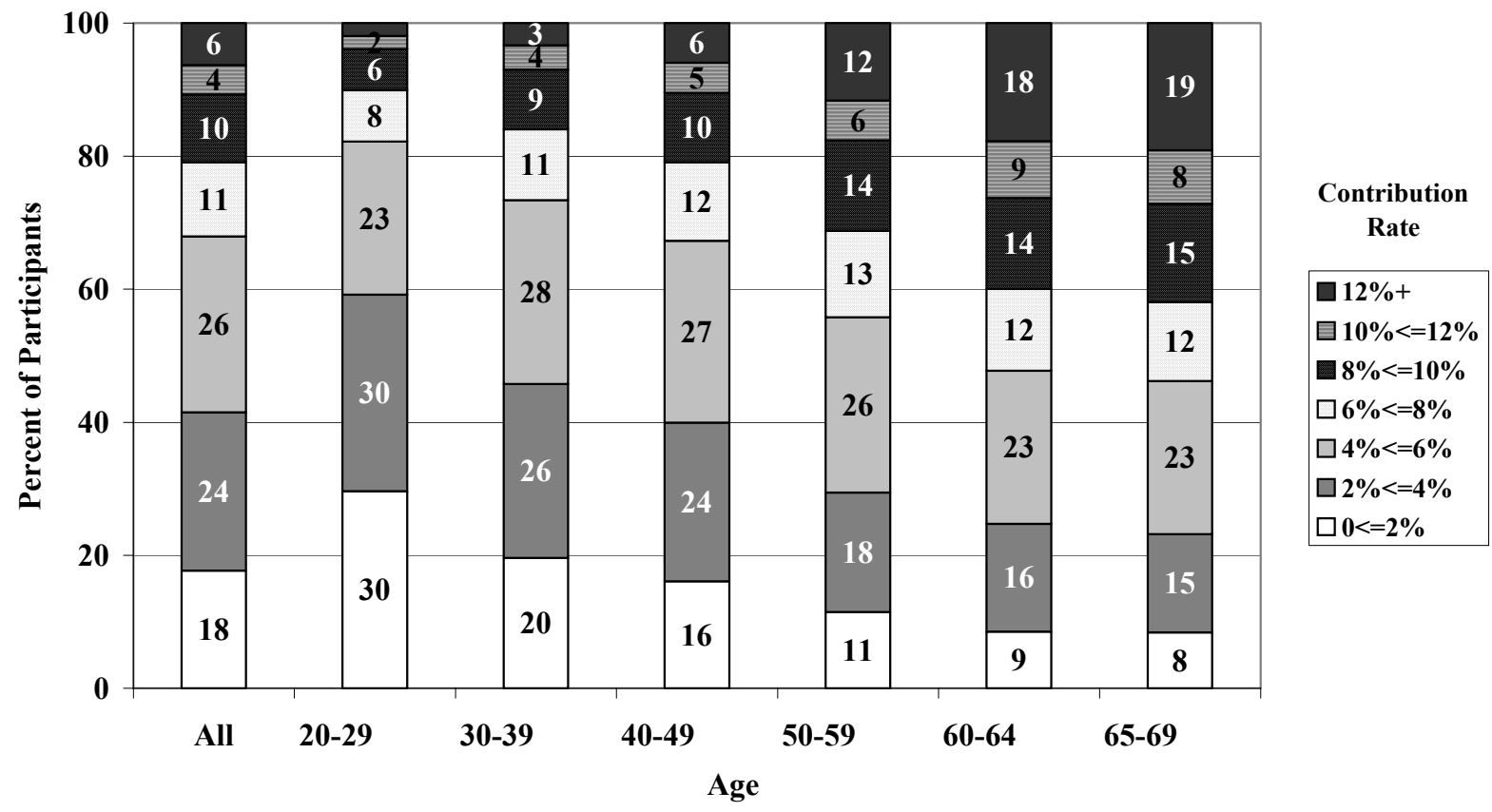

Note: The sample consists of 98,734 observations between 1990 and 2001 on workers ages 20 to 69 , who contributed to employer-sponsored tax-deferred retirement plans. The contribution rate is defined as the annual contribution amount divided by total annual earnings.

Source: Urban Institute tabulations of the 1996 SIPP matched to the Detailed Earnings Record.

Figure 10. Distribution of Husband's Contributions by Wife's Contribution, 1997

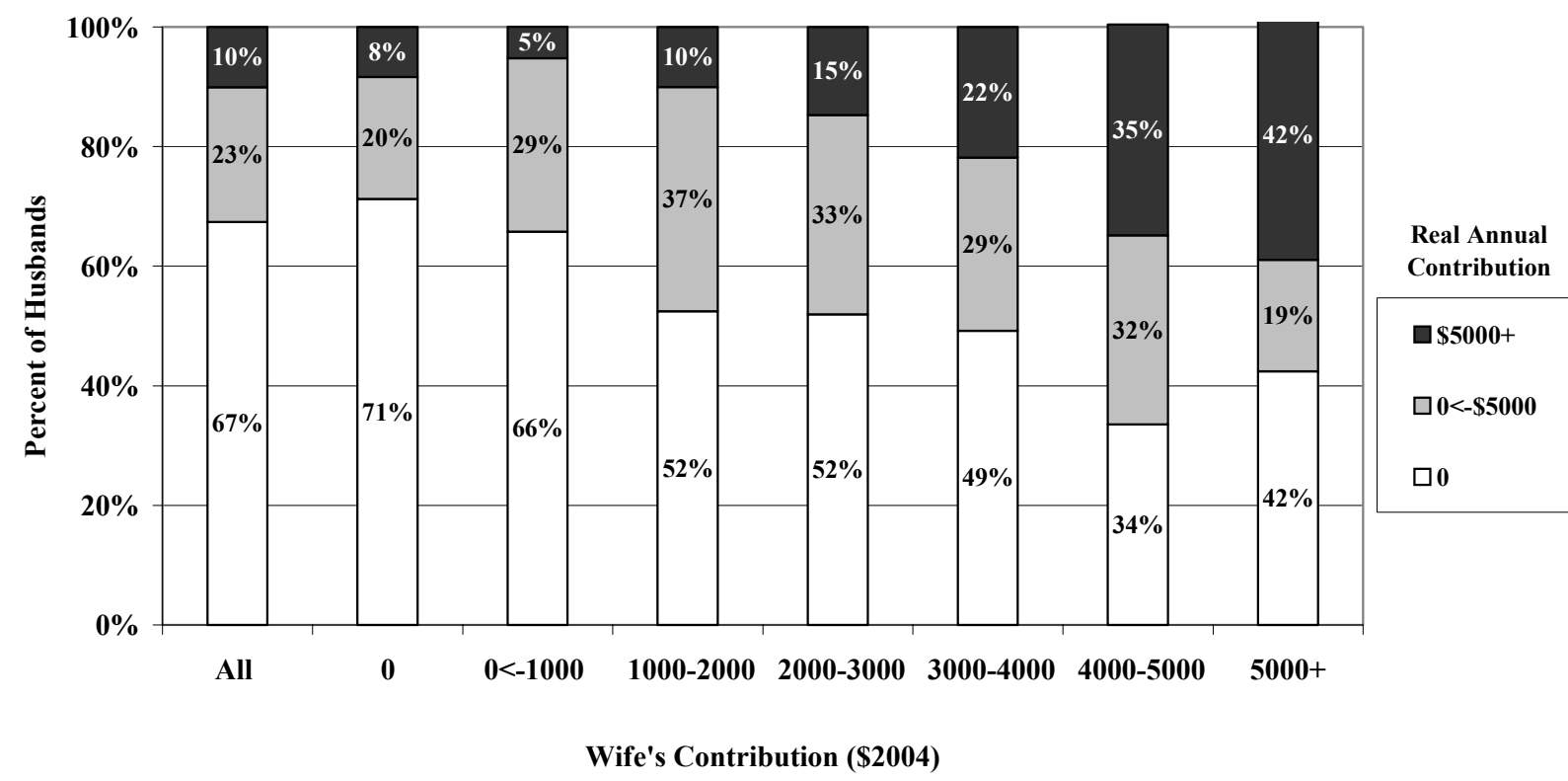

Note: The sample consists of 11,221 married couples in 1997, in which the husband was between the ages of 20 and 69 and information from the Detailed Earnings Record was available for both spouses. The sample includes respondents regardless of employment status or plan offers. Contribution amounts are expressed in constant 2004 dollars.

Source: Urban Institute tabulations of the 1996 SIPP matched to the Detailed Earnings Record. 
Figure 11. Distribution of Contribution Patterns between 1990 and 2001, by Age

(Defining Patterns Using a One-Percentage-Point Change in the Contribution Rate)

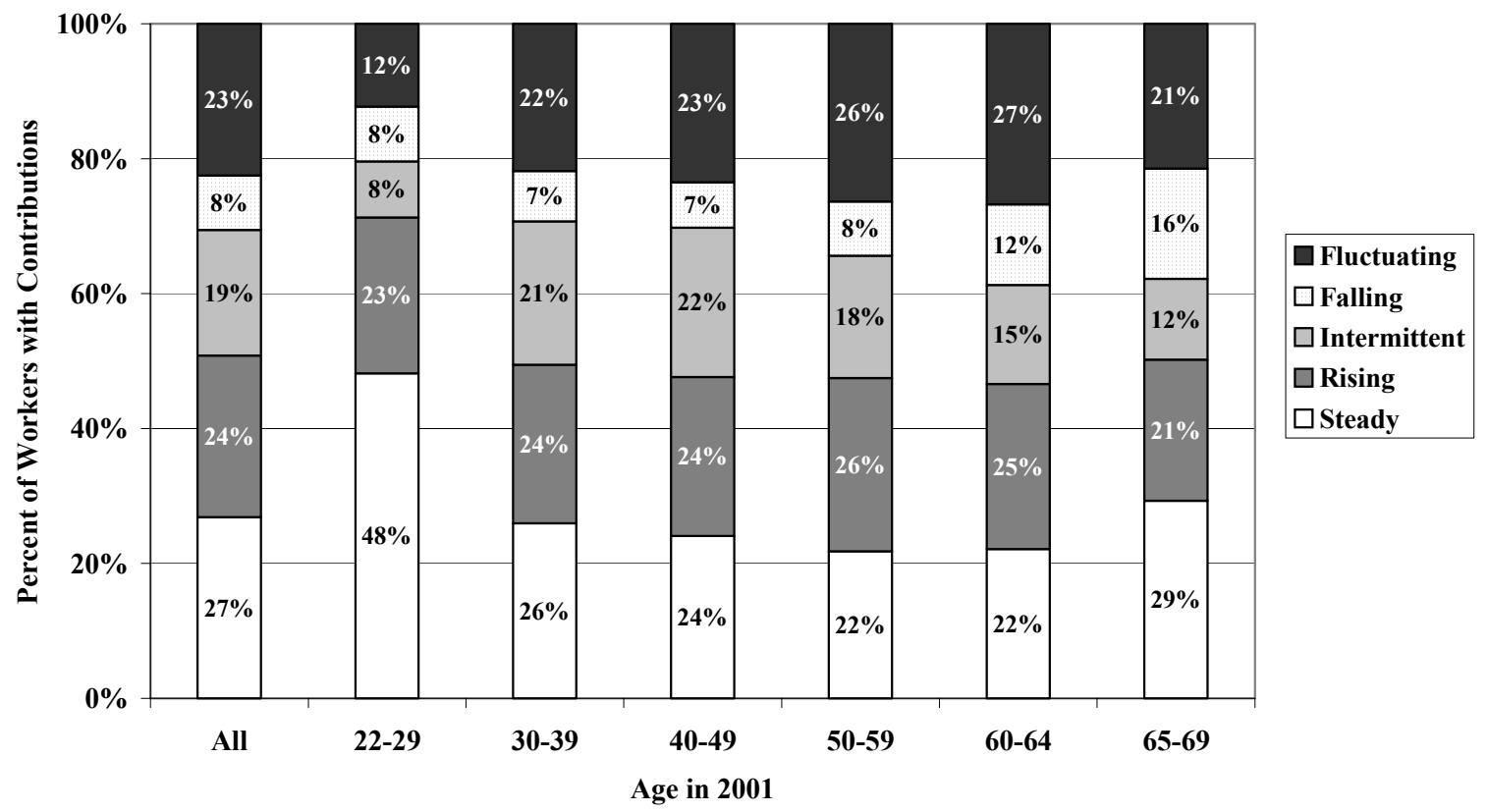

Note: The sample includes 17,266 respondents ages 20 to 69 in 2001 who contributed to an employer-sponsored tax-deferred retirement plan at some point between 1990 and 2001. Definitions of contribution patterns are provided in the text.

Source: Urban Institute tabulations of the 1996 SIPP matched to the Detailed Earnings Record.

Figure 12. Distribution of Contribution Patterns between 1990 and 2001, by Years of Contributions (Defining Patterns Using a One-Percentage-Point Change in the Contribution Rate)

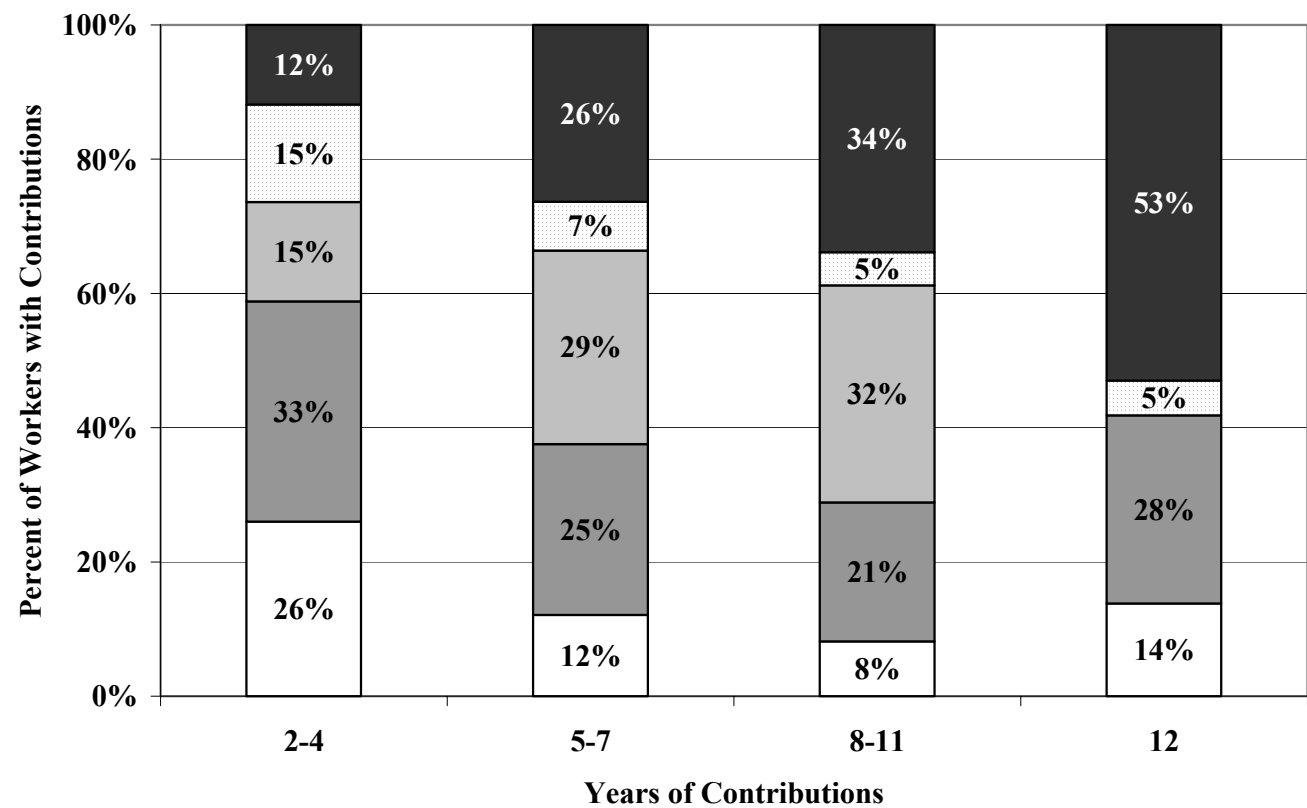

Fluctuating

$\square$ Falling

$\square$ Intermittent

$\square$ Rising

$\square$ Steady

Note: The sample includes 17,266 respondents ages 20 to 69 in 2001 who contributed to an employer-sponsored tax-deferred retirement plan at some point between 1990 and 2001. Definitions of contribution patterns are provided in the text.

Source: Urban Institute tabulations of the 1996 SIPP matched to the Detailed Earnings Record. 
Figure 13. Distribution of Contribution Patterns between 1990 and 2001, by Average Real Earnings (Defining Patterns Using a One-Percentage-Point Change in the Contribution Rate)

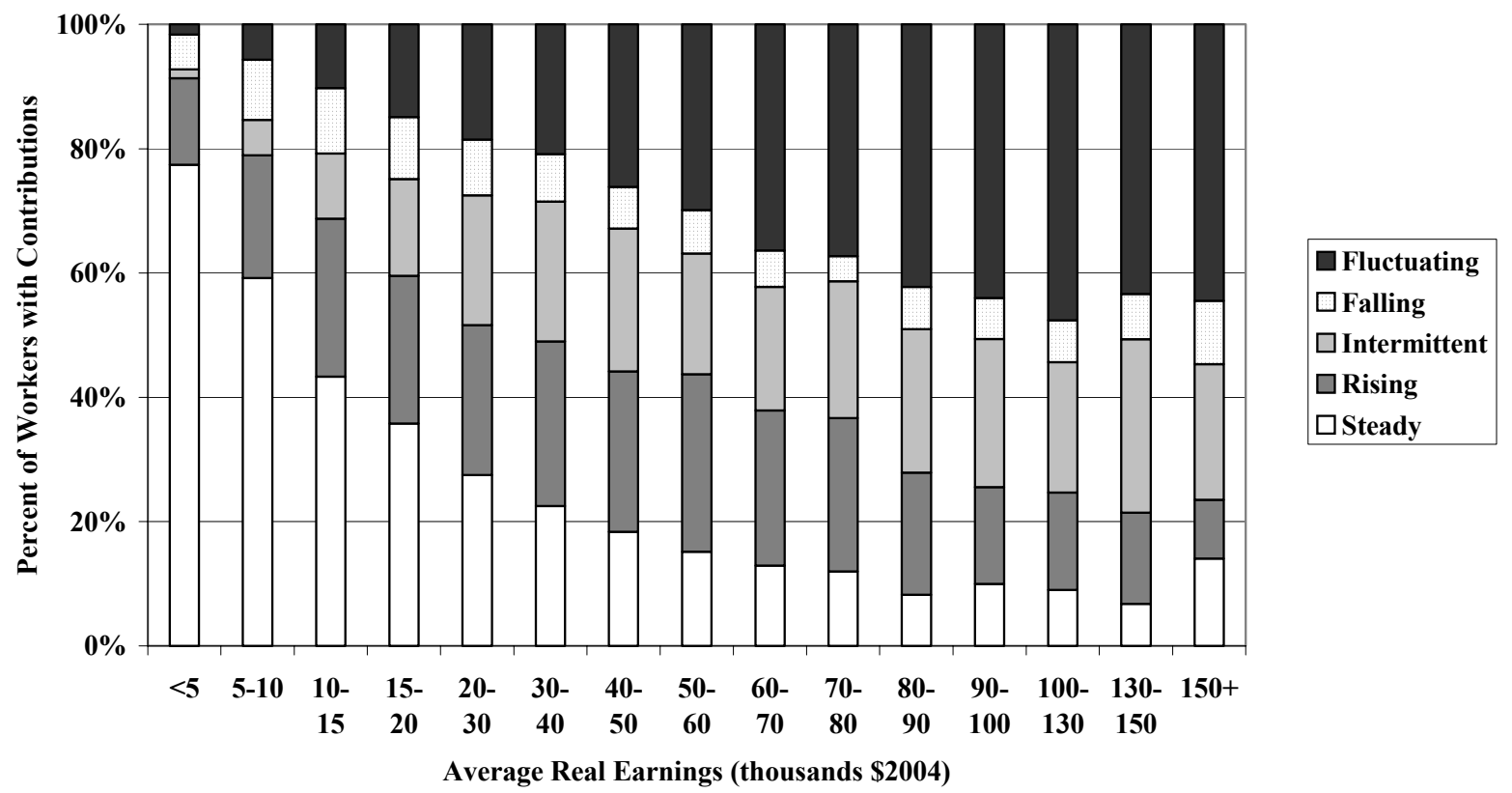

Note: The sample includes 17,266 respondents ages 20 to 69 in 2001 who contributed to an employer-sponsored tax-deferred retirement plan at some point between 1990 and 2001. Definitions of contribution patterns are provided in the text. Earnings are expressed in constant 2004 dollars.

Source: Urban Institute tabulations of the 1996 SIPP matched to the Detailed Earnings Record.

Figure 14. Distribution of Contribution Patterns between 1990 and 2001, by Average Real Earnings (Defining Patterns Using a 10\% Change in the Nominal Contribution Amount)

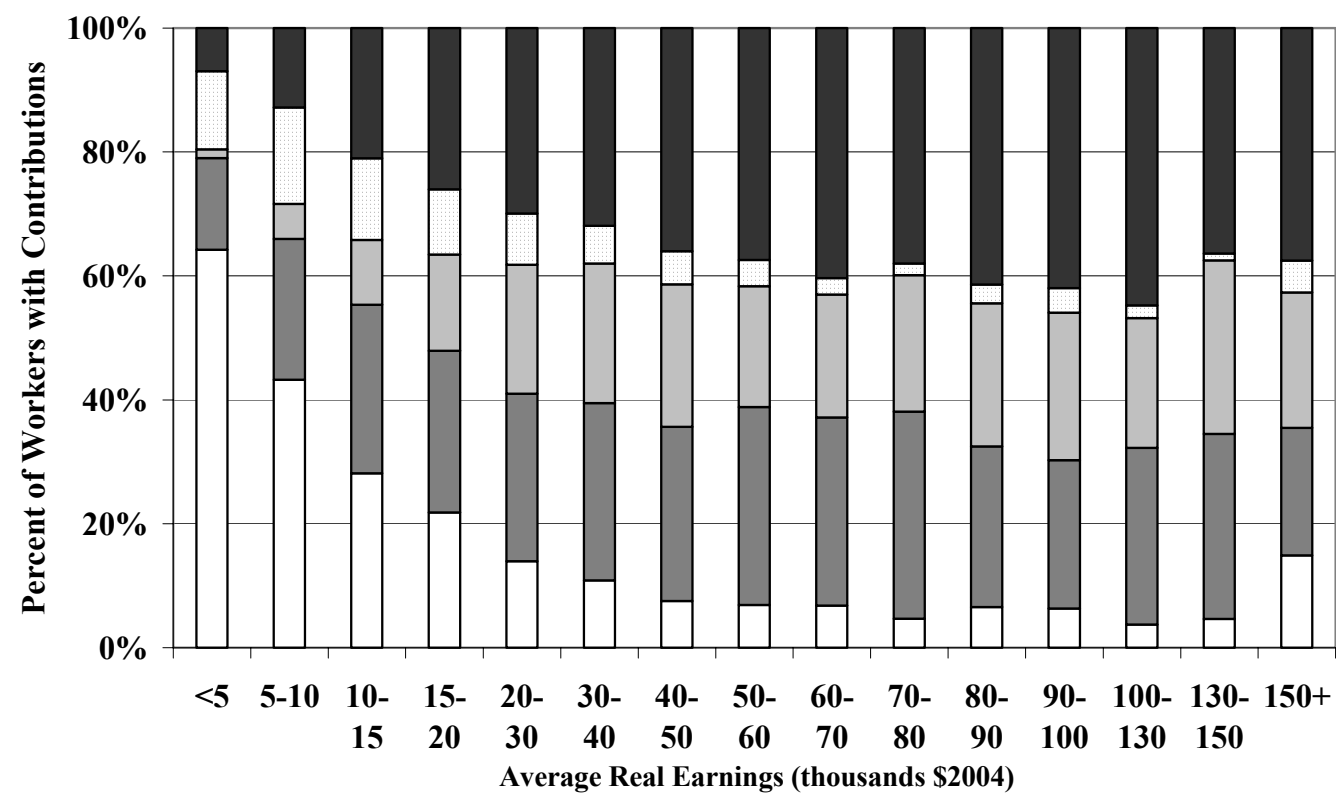

$\square$ Fluctuating $\square$ Falling $\square$ Intermittent $\square$ Rising $\square$ Steady

Note: The sample includes 17,266 respondents ages 20 to 69 in 2001 who contributed to an employer-sponsored tax-deferred retirement plan at some point between 1990 and 2001. Definitions of contribution patterns are provided in the text. Earnings are expressed in constant 2004 dollars.

Source: Urban Institute tabulations of the 1996 SIPP matched to the Detailed Earnings Record. 
TABLE 1

PARTICIPATION RATES FOR WORKERS AGES 20 TO 69 BY YEAR, 1990 to 2001

\begin{tabular}{lccccccc}
\hline & & \multicolumn{7}{c}{ Age } \\
& All & $\mathbf{2 0 - 2 9}$ & $\mathbf{3 0 - 3 9}$ & $\mathbf{4 0 - 4 9}$ & $\mathbf{5 0 - 5 9}$ & $\mathbf{6 0 - 6 4}$ & $\mathbf{6 5 - 6 9}$ \\
\hline Year & & & & & & & \\
All & 0.27 & 0.14 & 0.29 & 0.33 & 0.34 & 0.25 & 0.12 \\
$\mathbf{1 9 9 0}$ & 0.17 & 0.09 & 0.19 & 0.21 & 0.22 & 0.20 & 0.07 \\
$\mathbf{1 9 9 1}$ & 0.19 & 0.11 & 0.22 & 0.24 & 0.25 & 0.19 & 0.12 \\
$\mathbf{1 9 9 2}$ & 0.21 & 0.12 & 0.23 & 0.27 & 0.27 & 0.20 & 0.11 \\
$\mathbf{1 9 9 3}$ & 0.22 & 0.12 & 0.25 & 0.28 & 0.28 & 0.19 & 0.09 \\
$\mathbf{1 9 9 4}$ & 0.24 & 0.13 & 0.27 & 0.30 & 0.30 & 0.21 & 0.12 \\
$\mathbf{1 9 9 5}$ & 0.26 & 0.14 & 0.29 & 0.32 & 0.32 & 0.22 & 0.12 \\
$\mathbf{1 9 9 6}$ & 0.28 & 0.15 & 0.31 & 0.34 & 0.34 & 0.23 & 0.13 \\
$\mathbf{1 9 9 7}$ & 0.30 & 0.17 & 0.33 & 0.36 & 0.36 & 0.26 & 0.13 \\
$\mathbf{1 9 9 8}$ & 0.31 & 0.18 & 0.35 & 0.38 & 0.38 & 0.28 & 0.14 \\
$\mathbf{1 9 9 9}$ & 0.33 & 0.18 & 0.35 & 0.40 & 0.40 & 0.31 & 0.14 \\
$\mathbf{2 0 0 0}$ & 0.33 & 0.18 & 0.36 & 0.41 & 0.41 & 0.31 & 0.14 \\
$\mathbf{2 0 0 1}$ & 0.34 & 0.18 & 0.37 & 0.40 & 0.41 & 0.32 & 0.17 \\
\hline
\end{tabular}

Note: The sample consists of 373,971 observations between 1990 and 2001 on workers ages 20 to 69, including those not offered defined contribution retirement plans by their employers.

Source: Urban Institute tabulations of the 1996 SIPP matched to the Detailed Earnings Record. 
TABLE 2

PARTICIPATION RATE AMONG WORKERS OFFERED A PLAN, BY PERSONAL CHARACTERISTICS, 1997

\begin{tabular}{lcrrrrrr}
\hline & & & & Age & & & \\
& All & $\mathbf{2 0 - 2 9}$ & $\mathbf{3 0 - 3 9}$ & $\mathbf{4 0 - 4 9}$ & $\mathbf{5 0 - 5 9}$ & $\mathbf{6 0 - 6 4}$ & $\mathbf{6 5 - 6 9}$ \\
\cline { 2 - 8 } $\begin{array}{l}\text { All } \\
\text { Sex }\end{array} \quad 0.72$ & 0.63 & 0.73 & 0.73 & 0.74 & 0.73 & 0.71 \\
$\quad$ Male & & & & & & & \\
$\quad$ Female & 0.72 & 0.63 & 0.74 & 0.72 & 0.74 & 0.74 & 0.67 \\
Marital Status & 0.72 & 0.64 & 0.71 & 0.75 & 0.75 & 0.72 & 0.75 \\
$\quad$ Never Married & & & & & & & \\
$\quad$ Married & 0.67 & 0.61 & 0.73 & 0.72 & 0.72 & 0.52 & 0.66 \\
$\quad$ Widowed & 0.73 & 0.67 & 0.73 & 0.75 & 0.75 & 0.73 & 0.67 \\
$\quad$ Divorced & 0.73 & & 0.66 & 0.60 & 0.72 & 0.91 & 0.75 \\
Race/Ethnicity & 0.70 & 0.54 & 0.68 & 0.69 & 0.73 & 0.71 & 0.95 \\
$\quad$ Non-Hispanic White & & & & & & & \\
$\quad$ Non-Hispanic Black & 0.73 & 0.65 & 0.73 & 0.74 & 0.74 & 0.74 & 0.70 \\
$\quad$ Hispanic & 0.67 & 0.53 & 0.68 & 0.70 & 0.70 & 0.82 & 0.36 \\
$\quad$ Other & 0.66 & 0.59 & 0.69 & 0.63 & 0.75 & 0.58 & 1.00 \\
Education & 0.76 & 0.72 & 0.77 & 0.75 & 0.80 & 0.59 & 1.00 \\
$\quad$ Did Not Complete High School & 0.58 & 0.44 & 0.54 & 0.60 & 0.62 & 0.65 & 0.72 \\
$\quad$ High School Graduate & 0.69 & 0.60 & 0.70 & 0.70 & 0.73 & 0.72 & 0.73 \\
$\quad$ College Graduate & 0.78 & 0.71 & 0.79 & 0.80 & 0.78 & 0.77 & 0.67 \\
\hline
\end{tabular}

Note: The sample consists of 13,108 workers ages 20 to 69 in 1997 whose employers offered them tax-deferred retirement plans.

Source: Urban Institute tabulations of the 1996 SIPP matched to the Detailed Earnings Record. 
TABLE 3

AVERAGE ANNUAL REAL CONTRIBUTION AMOUNT AND CONTRIBUTION RATE AMONG PLAN PARTICIPANTS, BY AGE AND YEAR, 1990 to 2001

\begin{tabular}{|c|c|c|c|c|c|c|c|}
\hline & & & & Age & & & \\
\hline & All & $20-29$ & 30-39 & 40-49 & $50-59$ & $60-64$ & $65-69$ \\
\hline Year & & & ge Annt & ntributi & lount (\$) & & \\
\hline All & 3,288 & 1,750 & 2,899 & 3,596 & 4,219 & 4,351 & 3,713 \\
\hline 1990 & 3,158 & 1,488 & 2,427 & 3,791 & 4,546 & 4,527 & 6,301 \\
\hline 1991 & 2,958 & 1,770 & 2,429 & 3,244 & 4,146 & 4,478 & 4,108 \\
\hline 1992 & 2,986 & 1,813 & 2,426 & 3,279 & 4,180 & 4,450 & 3,437 \\
\hline 1993 & 3,038 & 1,413 & 2,598 & 3,427 & 4,187 & 4,318 & 3,952 \\
\hline 1994 & 3,049 & 1,530 & 2,572 & 3,457 & 4,129 & 4,065 & 4,007 \\
\hline 1995 & 3,043 & 1,458 & 2,599 & 3,474 & 4,061 & 3,757 & 4,119 \\
\hline 1996 & 3,113 & 1,571 & 2,726 & 3,416 & 4,087 & 4,074 & 3,589 \\
\hline 1997 & 3,208 & 1,685 & 2,948 & 3,446 & 4,082 & 4,253 & 3,496 \\
\hline 1998 & 3,413 & 1,913 & 3,067 & 3,628 & 4,357 & 4,390 & 3,727 \\
\hline 1999 & 3,482 & 1,825 & 3,249 & 3,708 & 4,179 & 4,822 & 3,158 \\
\hline 2000 & 3,719 & 1,897 & 3,497 & 4,100 & 4,367 & 4,405 & 2,980 \\
\hline 2001 & 3,637 & 2,275 & 3,494 & 3,735 & 4,278 & 4,385 & 3,558 \\
\hline & & verage & bution 1 & deferrec & ibution/ & arning & \\
\hline All & $5.4 \%$ & $3.9 \%$ & $4.8 \%$ & $5.4 \%$ & $6.5 \%$ & $7.5 \%$ & $7.6 \%$ \\
\hline 1990 & $5.0 \%$ & $3.6 \%$ & $4.3 \%$ & $5.1 \%$ & $6.8 \%$ & $7.5 \%$ & $8.6 \%$ \\
\hline 1991 & $4.9 \%$ & $3.6 \%$ & $4.3 \%$ & $5.0 \%$ & $6.4 \%$ & $7.8 \%$ & $7.6 \%$ \\
\hline 1992 & $5.0 \%$ & $3.7 \%$ & $4.4 \%$ & $5.0 \%$ & $6.4 \%$ & $7.8 \%$ & $7.7 \%$ \\
\hline 1993 & $5.1 \%$ & $3.5 \%$ & $4.6 \%$ & $5.2 \%$ & $6.6 \%$ & $7.7 \%$ & $8.3 \%$ \\
\hline 1994 & $5.2 \%$ & $3.9 \%$ & $4.6 \%$ & $5.3 \%$ & $6.5 \%$ & $7.4 \%$ & $8.1 \%$ \\
\hline 1995 & $5.2 \%$ & $3.7 \%$ & $4.7 \%$ & $5.3 \%$ & $6.4 \%$ & $6.8 \%$ & $8.3 \%$ \\
\hline 1996 & $5.3 \%$ & $3.8 \%$ & $4.8 \%$ & $5.4 \%$ & $6.5 \%$ & $7.3 \%$ & $7.7 \%$ \\
\hline 1997 & $5.4 \%$ & $4.1 \%$ & $4.9 \%$ & $5.4 \%$ & $6.5 \%$ & $7.3 \%$ & $7.6 \%$ \\
\hline 1998 & $5.5 \%$ & $4.3 \%$ & $5.0 \%$ & $5.5 \%$ & $6.6 \%$ & $7.3 \%$ & $7.4 \%$ \\
\hline 1999 & $5.6 \%$ & $4.1 \%$ & $5.2 \%$ & $5.5 \%$ & $6.5 \%$ & $7.5 \%$ & $7.4 \%$ \\
\hline 2000 & $5.6 \%$ & $4.1 \%$ & $5.2 \%$ & $5.6 \%$ & $6.5 \%$ & $7.6 \%$ & $7.0 \%$ \\
\hline 2001 & $5.7 \%$ & $4.3 \%$ & $5.2 \%$ & $5.7 \%$ & $6.5 \%$ & $7.6 \%$ & $7.3 \%$ \\
\hline
\end{tabular}

Note: The sample consists of 98,734 observations between 1990 and 2001 on workers ages 20 to 69 who contributed to employer-sponsored tax-deferred retirement plans. Contribution amounts are expressed in constant 2004 dollars.

Source: Urban Institute tabulations of the 1996 SIPP matched to the Detailed Earnings Record. 
TABLE 4

NUMBER OF MARRIED COUPLES BY CONTRIBUTIONS TO EMPLOYER-SPONSORED TAX-DEFERRED RETIREMENT PLANS, 1997

\begin{tabular}{|c|c|c|c|c|c|c|c|c|}
\hline & \multicolumn{8}{|c|}{ Wife's Contribution (\$2004) } \\
\hline & All & $\mathbf{0}$ & $0<-1000$ & $\begin{array}{l}1000- \\
2000\end{array}$ & $\begin{array}{l}\text { 2000- } \\
3000\end{array}$ & $\begin{array}{l}3000- \\
4000\end{array}$ & $\begin{array}{l}4000- \\
5000\end{array}$ & $5000+$ \\
\hline & \multicolumn{8}{|c|}{ Thousands of Couples } \\
\hline \multicolumn{9}{|c|}{ Husband's Contribution (\$2004) } \\
\hline All & 39,867 & 31,093 & 2,763 & 1,990 & 1,428 & 746 & 462 & 1,384 \\
\hline $\mathbf{0}$ & 26,865 & 22,153 & 1,817 & 1,044 & 742 & 367 & 155 & 587 \\
\hline $0<-1000$ & 2,217 & 1,627 & 306 & 140 & 72 & 28 & 12 & 32 \\
\hline $1000-2000$ & 2,343 & 1,637 & 281 & 217 & 92 & 64 & 23 & 29 \\
\hline 2000-3000 & 1,918 & 1,333 & 94 & 177 & 158 & 40 & 43 & 73 \\
\hline $3000-4000$ & 1,439 & 997 & 57 & 141 & 76 & 47 & 37 & 85 \\
\hline $4000-5000$ & 1,069 & 750 & 63 & 71 & 78 & 37 & 31 & 39 \\
\hline \multirow[t]{2}{*}{$5000+$} & 4,016 & 2,596 & 146 & 200 & 210 & 163 & 163 & 579 \\
\hline & \multicolumn{8}{|c|}{ Column Percent } \\
\hline All & $100 \%$ & $100 \%$ & $100 \%$ & $100 \%$ & $100 \%$ & $100 \%$ & $100 \%$ & $100 \%$ \\
\hline $\mathbf{0}$ & $67 \%$ & $71 \%$ & $66 \%$ & $52 \%$ & $52 \%$ & $49 \%$ & $34 \%$ & $42 \%$ \\
\hline $0<-1000$ & $6 \%$ & $5 \%$ & $11 \%$ & $7 \%$ & $5 \%$ & $4 \%$ & $3 \%$ & $2 \%$ \\
\hline $1000-2000$ & $6 \%$ & $5 \%$ & $10 \%$ & $11 \%$ & $6 \%$ & $9 \%$ & $5 \%$ & $2 \%$ \\
\hline 2000-3000 & $5 \%$ & $4 \%$ & $3 \%$ & $9 \%$ & $11 \%$ & $5 \%$ & $9 \%$ & $5 \%$ \\
\hline $3000-4000$ & $4 \%$ & $3 \%$ & $2 \%$ & $7 \%$ & $5 \%$ & $6 \%$ & $8 \%$ & $6 \%$ \\
\hline $4000-5000$ & $3 \%$ & $2 \%$ & $2 \%$ & $4 \%$ & $5 \%$ & $5 \%$ & $7 \%$ & $3 \%$ \\
\hline \multirow[t]{2}{*}{$5000+$} & $10 \%$ & $8 \%$ & $5 \%$ & $10 \%$ & $15 \%$ & $22 \%$ & $35 \%$ & $42 \%$ \\
\hline & \multicolumn{8}{|c|}{$\underline{\text { Row Percent }}$} \\
\hline $\mathbf{0}$ & $100 \%$ & $82 \%$ & $7 \%$ & $4 \%$ & $3 \%$ & $1 \%$ & $1 \%$ & $2 \%$ \\
\hline $0<-1000$ & $100 \%$ & $73 \%$ & $14 \%$ & $6 \%$ & $3 \%$ & $1 \%$ & $1 \%$ & $1 \%$ \\
\hline $1000-2000$ & $100 \%$ & $70 \%$ & $12 \%$ & $9 \%$ & $4 \%$ & $3 \%$ & $1 \%$ & $1 \%$ \\
\hline 2000-3000 & $100 \%$ & $69 \%$ & $5 \%$ & $9 \%$ & $8 \%$ & $2 \%$ & $2 \%$ & $4 \%$ \\
\hline $3000-4000$ & $100 \%$ & $69 \%$ & $4 \%$ & $10 \%$ & $5 \%$ & $3 \%$ & $3 \%$ & $6 \%$ \\
\hline $4000-5000$ & $100 \%$ & $70 \%$ & $6 \%$ & $7 \%$ & $7 \%$ & $3 \%$ & $3 \%$ & $4 \%$ \\
\hline $5000+$ & $100 \%$ & $65 \%$ & $4 \%$ & $5 \%$ & $5 \%$ & $4 \%$ & $4 \%$ & $14 \%$ \\
\hline
\end{tabular}

Note: The sample consists of 11,221 married couples in 1997, in which the husband was between the ages of 20 and 69 and information from the Detailed Earnings Record was available for both spouses. The sample includes respondents regardless of employment status or plan offers. Contribution amounts are expressed in constant 2004 dollars.

Source: Urban Institute tabulations of the 1996 SIPP matched to the Detailed Earnings Record. 
TABLE 5

SHARE OF INDIVIDUALS AGES 20 TO 69 in 2001, BY THE NUMBER OF YEARS WITH CONTRIBUTIONS TO TAX-DEFERRED RETIREMENT PLANS, 1990 TO 2001

\begin{tabular}{|c|c|c|c|c|c|c|c|}
\hline & \multicolumn{7}{|c|}{ Age } \\
\hline & All & 20-29 & 30-39 & 40-49 & 50-59 & $60-64$ & 65-69 \\
\hline \multicolumn{8}{|c|}{$\begin{array}{l}\text { Number of Years with } \\
\text { Contributions }\end{array}$} \\
\hline & \multicolumn{7}{|c|}{ Percent of Individuals } \\
\hline $\mathbf{0}$ & $58 \%$ & $77 \%$ & $50 \%$ & $51 \%$ & $53 \%$ & $61 \%$ & $72 \%$ \\
\hline 1 & $5 \%$ & $8 \%$ & $6 \%$ & $5 \%$ & $4 \%$ & $2 \%$ & $3 \%$ \\
\hline $2-4$ & $14 \%$ & $12 \%$ & $19 \%$ & $14 \%$ & $12 \%$ & $10 \%$ & $9 \%$ \\
\hline $5-6$ & $7 \%$ & $2 \%$ & $9 \%$ & $8 \%$ & $7 \%$ & $7 \%$ & $6 \%$ \\
\hline $7-10$ & $10 \%$ & $1 \%$ & $11 \%$ & $13 \%$ & $14 \%$ & $12 \%$ & $8 \%$ \\
\hline 11-12 & $6 \%$ & $0 \%$ & $4 \%$ & $10 \%$ & $12 \%$ & $7 \%$ & $2 \%$ \\
\hline \multirow[t]{2}{*}{ All } & $100 \%$ & $100 \%$ & $100 \%$ & $100 \%$ & $100 \%$ & $100 \%$ & $100 \%$ \\
\hline & \multicolumn{7}{|c|}{ Percent of Men } \\
\hline $\mathbf{0}$ & $55 \%$ & $77 \%$ & $47 \%$ & $47 \%$ & $49 \%$ & $55 \%$ & $69 \%$ \\
\hline 1 & $5 \%$ & $8 \%$ & $6 \%$ & $4 \%$ & $4 \%$ & $2 \%$ & $3 \%$ \\
\hline $2-4$ & $14 \%$ & $12 \%$ & $19 \%$ & $14 \%$ & $11 \%$ & $12 \%$ & $10 \%$ \\
\hline $5-6$ & $7 \%$ & $2 \%$ & $11 \%$ & $8 \%$ & $7 \%$ & $8 \%$ & $7 \%$ \\
\hline $7-10$ & $11 \%$ & $1 \%$ & $13 \%$ & $14 \%$ & $15 \%$ & $14 \%$ & $8 \%$ \\
\hline $11-12$ & $8 \%$ & $0 \%$ & $5 \%$ & $12 \%$ & $14 \%$ & $9 \%$ & $3 \%$ \\
\hline \multirow[t]{2}{*}{ All } & $100 \%$ & $100 \%$ & $100 \%$ & $100 \%$ & $100 \%$ & $100 \%$ & $100 \%$ \\
\hline & \multicolumn{7}{|c|}{ Percent of Women } \\
\hline $\mathbf{0}$ & $61 \%$ & $77 \%$ & $54 \%$ & $54 \%$ & $56 \%$ & $67 \%$ & $75 \%$ \\
\hline 1 & $5 \%$ & $8 \%$ & $6 \%$ & $5 \%$ & $4 \%$ & $2 \%$ & $4 \%$ \\
\hline $2-4$ & $14 \%$ & $12 \%$ & $19 \%$ & $14 \%$ & $12 \%$ & $8 \%$ & $8 \%$ \\
\hline $5-6$ & $6 \%$ & $3 \%$ & $8 \%$ & $8 \%$ & $7 \%$ & $6 \%$ & $4 \%$ \\
\hline $7-10$ & $9 \%$ & $1 \%$ & $10 \%$ & $11 \%$ & $12 \%$ & $11 \%$ & $7 \%$ \\
\hline 11-12 & $5 \%$ & $0 \%$ & $3 \%$ & $8 \%$ & $9 \%$ & $6 \%$ & $1 \%$ \\
\hline All & $100 \%$ & $100 \%$ & $100 \%$ & $100 \%$ & $100 \%$ & $100 \%$ & $100 \%$ \\
\hline
\end{tabular}

Note: The sample consists of 41,781 individuals between the ages of 20 and 69 in 2001, including those who were never offered tax-deferred retirement plans by their employers.

Source: Urban Institute tabulations of the 1996 SIPP matched to the Detailed Earnings Record. 
TABLE 6

LOGISTIC REGRESSION ESTIMATES OF WHETHER WORKERS WITH PLAN OFFERS CONTRIBUTE TO TAX-DEFERRED RETIREMENT PLANS, 1991 TO 1997

\begin{tabular}{|c|c|c|}
\hline & $\begin{array}{l}\text { Parameter } \\
\text { Estimate }\end{array}$ & $\begin{array}{c}\text { Standard } \\
\text { Error }\end{array}$ \\
\hline Intercept & $-12.1935 * *$ & 0.1650 \\
\hline Log of total earnings & $1.0742 * *$ & 0.0145 \\
\hline Age & $0.0322 * *$ & 0.0058 \\
\hline Age squared & $-0.0002 * *$ & 0.0001 \\
\hline Married & $-0.0779 * *$ & 0.0210 \\
\hline Two earners & $-0.5843 * *$ & 0.0208 \\
\hline Spouse contributes to a DC plan & 0.0129 & 0.0356 \\
\hline Spouse's contribution rate (contribution/earnings) & $2.9906 * *$ & 0.4992 \\
\hline Purchase a home this year & 0.0420 & 0.0444 \\
\hline Purchase a home last year & 0.1019 & 0.0460 \\
\hline Own a home & $0.2065 * *$ & 0.0175 \\
\hline Become divorced this year & -0.1575 & 0.0659 \\
\hline Become widowed this year & -0.0002 & 0.1943 \\
\hline Get married this year & -0.0207 & 0.0448 \\
\hline Number of dependents & $-0.0279 * *$ & 0.0082 \\
\hline Have a baby this year & $0.1925 * *$ & 0.0394 \\
\hline Have a baby last year & $0.1400 * *$ & 0.0386 \\
\hline Currently work limited & -0.0078 & 0.0530 \\
\hline Spouse currently work limited & $0.2027 * *$ & 0.0439 \\
\hline Become work limited this year & 0.0112 & 0.1698 \\
\hline Become work limited last year & 0.1377 & 0.1640 \\
\hline Have a DB plan & $0.0793 * *$ & 0.0150 \\
\hline Gets a job this year after unemployment & $-1.6343 * *$ & 0.1196 \\
\hline Spouse gets a job this year after unemployment & $0.2478 * *$ & 0.0603 \\
\hline Change jobs this year & $-0.4575 * *$ & 0.0186 \\
\hline Spouse changes jobs this year & $0.0805^{* *}$ & 0.0193 \\
\hline Change jobs this last year & $-0.3575 * *$ & 0.0209 \\
\hline Spouse changes jobs last year & 0.0425 & 0.0221 \\
\hline Spouses loses a job this year & -0.0335 & 0.0581 \\
\hline Spouse begins to contribute to DC plan this year & 0.0957 & 0.0494 \\
\hline Employer contributes to plan & $-0.1082 * *$ & 0.0163 \\
\hline Can borrow from pension plan & $0.1377 * *$ & 0.0164 \\
\hline $\mathrm{N}$ (person years) & 90634 & \\
\hline -2 log likelihood & 107498 & \\
\hline
\end{tabular}

Note: The sample consists of individuals ages 20 to 69 who were working in 1997 and whose employers offered tax-deferred retirement plans.

$$
* * p<0.001 ; * p<0.01
$$

Source: Urban Institute tabulations of the 1996 SIPP matched to the Detailed Earnings Record. 
TABLE A.1

PARTICIPATION RATES AMONG WORKERS AGES 20 TO 69 BY YEAR, AGE, AND OTHER PERSONAL CHARACTERISTICS, 1990 TO 2001

\begin{tabular}{|c|c|c|c|c|c|c|c|}
\hline & & & & Age & & & \\
\hline & All & $20-29$ & 30-39 & $40-49$ & $50-59$ & $60-64$ & $65-69$ \\
\hline All & 0.27 & 0.14 & 0.29 & 0.33 & 0.34 & 0.25 & 0.12 \\
\hline Year & & & & & & & \\
\hline 1990 & 0.17 & 0.09 & 0.19 & 0.21 & 0.22 & 0.20 & 0.07 \\
\hline 1991 & 0.19 & 0.11 & 0.22 & 0.24 & 0.25 & 0.19 & 0.12 \\
\hline 1992 & 0.21 & 0.12 & 0.23 & 0.27 & 0.27 & 0.20 & 0.11 \\
\hline 1993 & 0.22 & 0.12 & 0.25 & 0.28 & 0.28 & 0.19 & 0.09 \\
\hline 1994 & 0.24 & 0.13 & 0.27 & 0.30 & 0.30 & 0.21 & 0.12 \\
\hline 1995 & 0.26 & 0.14 & 0.29 & 0.32 & 0.32 & 0.22 & 0.12 \\
\hline 1996 & 0.28 & 0.15 & 0.31 & 0.34 & 0.34 & 0.23 & 0.13 \\
\hline 1997 & 0.30 & 0.17 & 0.33 & 0.36 & 0.36 & 0.26 & 0.13 \\
\hline 1998 & 0.31 & 0.18 & 0.35 & 0.38 & 0.38 & 0.28 & 0.14 \\
\hline 1999 & 0.33 & 0.18 & 0.35 & 0.40 & 0.40 & 0.31 & 0.14 \\
\hline 2000 & 0.33 & 0.18 & 0.36 & 0.41 & 0.41 & 0.31 & 0.14 \\
\hline 2001 & 0.34 & 0.18 & 0.37 & 0.40 & 0.41 & 0.32 & 0.17 \\
\hline Gender & & & & & & & \\
\hline Male & 0.28 & 0.15 & 0.32 & 0.35 & 0.36 & 0.24 & 0.11 \\
\hline Female & 0.25 & 0.14 & 0.27 & 0.31 & 0.31 & 0.25 & 0.14 \\
\hline Race/Ethnicity & & & & & & & \\
\hline Non-Hispanic White & 0.29 & 0.16 & 0.31 & 0.35 & 0.35 & 0.26 & 0.13 \\
\hline Non-Hispanic Black & 0.21 & 0.10 & 0.23 & 0.28 & 0.28 & 0.21 & 0.07 \\
\hline Hispanic & 0.17 & 0.11 & 0.19 & 0.21 & 0.22 & 0.19 & 0.10 \\
\hline Other & 0.27 & 0.14 & 0.32 & 0.34 & 0.31 & 0.24 & 0.14 \\
\hline Education & & & & & & & \\
\hline Less than High School & 0.11 & 0.05 & 0.10 & 0.14 & 0.15 & 0.14 & 0.07 \\
\hline High School Graduate & 0.24 & 0.13 & 0.25 & 0.30 & 0.32 & 0.24 & 0.13 \\
\hline College Graduate & 0.39 & 0.22 & 0.44 & 0.45 & 0.46 & 0.36 & 0.17 \\
\hline Marital Status & & & & & & & \\
\hline Never Married & 0.18 & 0.12 & 0.28 & 0.31 & 0.29 & 0.21 & 0.13 \\
\hline Married & 0.30 & 0.19 & 0.30 & 0.34 & 0.34 & 0.25 & 0.12 \\
\hline Widowed & 0.22 & 0.09 & 0.16 & 0.23 & 0.28 & 0.24 & 0.13 \\
\hline Divorced & 0.29 & 0.16 & 0.26 & 0.32 & 0.34 & 0.27 & 0.16 \\
\hline Total Own Earnings (\$2004) & & & & & & & \\
\hline $0<-5000$ & 0.01 & 0.01 & 0.02 & 0.01 & 0.02 & 0.02 & 0.01 \\
\hline $5000-10000$ & 0.03 & 0.02 & 0.03 & 0.03 & 0.04 & 0.05 & 0.04 \\
\hline $10000-15000$ & 0.06 & 0.05 & 0.07 & 0.06 & 0.08 & 0.12 & 0.09 \\
\hline $15000-20000$ & 0.12 & 0.09 & 0.13 & 0.14 & 0.15 & 0.16 & 0.17 \\
\hline $20000-30000$ & 0.22 & 0.19 & 0.21 & 0.23 & 0.26 & 0.26 & 0.24 \\
\hline $30000-40000$ & 0.33 & 0.31 & 0.34 & 0.34 & 0.36 & 0.34 & 0.27 \\
\hline $40000-50000$ & 0.44 & 0.44 & 0.45 & 0.44 & 0.44 & 0.39 & 0.31 \\
\hline $50000-60000$ & 0.52 & 0.53 & 0.52 & 0.51 & 0.52 & 0.47 & 0.39 \\
\hline $60000-70000$ & 0.59 & 0.60 & 0.59 & 0.58 & 0.59 & 0.56 & 0.43 \\
\hline $70000-80000$ & 0.61 & 0.59 & 0.62 & 0.61 & 0.61 & 0.55 & 0.47 \\
\hline $80000-90000$ & 0.67 & 0.64 & 0.69 & 0.67 & 0.71 & 0.56 & 0.50 \\
\hline 90000-100000 & 0.70 & 0.73 & 0.71 & 0.72 & 0.70 & 0.64 & 0.41 \\
\hline $100000-130000$ & 0.72 & 0.70 & 0.71 & 0.73 & 0.74 & 0.66 & 0.43 \\
\hline $130000-150000$ & 0.68 & 0.67 & 0.70 & 0.66 & 0.70 & 0.69 & 0.48 \\
\hline $150000+$ & 0.60 & 0.77 & 0.64 & 0.59 & 0.57 & 0.58 & 0.39 \\
\hline Family Earnings (\$2004) & & & & & & & \\
\hline $0<-5000$ & 0.01 & 0.01 & 0.01 & 0.01 & 0.02 & 0.02 & 0.01 \\
\hline $5000-10000$ & 0.03 & 0.02 & 0.02 & 0.03 & 0.04 & 0.05 & 0.05 \\
\hline $10000-15000$ & 0.05 & 0.04 & 0.05 & 0.04 & 0.06 & 0.10 & 0.08 \\
\hline $15000-20000$ & 0.09 & 0.07 & 0.10 & 0.10 & 0.12 & 0.11 & 0.13 \\
\hline 20000-30000 & 0.17 & 0.14 & 0.16 & 0.18 & 0.20 & 0.22 & 0.16 \\
\hline $30000-40000$ & 0.23 & 0.21 & 0.23 & 0.23 & 0.27 & 0.28 & 0.20 \\
\hline $40000-50000$ & 0.29 & 0.26 & 0.29 & 0.29 & 0.31 & 0.29 & 0.22 \\
\hline $50000-60000$ & 0.32 & 0.29 & 0.32 & 0.34 & 0.33 & 0.32 & 0.23 \\
\hline $60000-70000$ & 0.37 & 0.34 & 0.37 & 0.38 & 0.38 & 0.40 & 0.42 \\
\hline $70000-80000$ & 0.41 & 0.36 & 0.42 & 0.41 & 0.44 & 0.43 & 0.30 \\
\hline $80000-90000$ & 0.47 & 0.40 & 0.48 & 0.46 & 0.51 & 0.46 & 0.46 \\
\hline 90000-100000 & 0.50 & 0.45 & 0.51 & 0.50 & 0.53 & 0.52 & 0.40 \\
\hline $100000-130000$ & 0.55 & 0.50 & 0.55 & 0.54 & 0.59 & 0.52 & 0.36 \\
\hline $130000-150000$ & 0.59 & 0.52 & 0.57 & 0.58 & 0.62 & 0.63 & 0.50 \\
\hline $150000+$ & 0.59 & 0.57 & 0.62 & 0.57 & 0.59 & 0.56 & 0.40 \\
\hline
\end{tabular}

Note: The sample consists of 373,971 observations between 1990 and 2001 on workers ages 20 to 69 , including those not offered defined contribution retirement plans by their employers. Annual earnings are expressed in constant 2004 dollars.

Source: Urban Institute tabulations of the 1996 SIPP matched to the Detailed Earnings Record. 
TABLE A.2

SHARE OF WORKERS AGES 20 TO 69 OFFERED AN EMPLOYER-SPONSORED TAX-DEFERRED RETIREMENT PLAN, BY AGE AND OTHER PERSONAL CHARACTERISTICS, 1997

All

Gender

Male

Female

Race/Ethnicity

Non-Hispanic White

Non-Hispanic Black

Hispanic

Other

Education

Less than High School

High School Graduate

College Graduate

Marital Status

Never Married

Married

Widowed

Divorced

Total Own Earnings (\$2004)

$0<-5000$

5000-10000

10000-15000

15000-20000

20000-30000

30000-40000

40000-50000

50000-60000

60000-70000

70000-80000

80000-90000

90000-100000

100000-130000

130000-150000

$150000+$

Family Earnings (\$2004)

$0<-5000$

5000-10000

10000-15000

15000-20000

20000-30000

30000-40000

40000-50000

50000-60000

60000-70000

70000-80000

80000-90000

90000-100000

100000-130000

130000-150000

$150000+$

\begin{tabular}{|c|c|c|c|c|c|c|}
\hline \multicolumn{7}{|c|}{ Age } \\
\hline All & 20-29 & 30-39 & 40-49 & $50-59$ & $60-64$ & 65-69 \\
\hline 0.42 & 0.27 & 0.46 & 0.49 & 0.49 & 0.35 & 0.19 \\
\hline 0.44 & 0.28 & 0.50 & 0.52 & 0.52 & 0.35 & 0.17 \\
\hline 0.39 & 0.26 & 0.41 & 0.46 & 0.44 & 0.35 & 0.21 \\
\hline 0.44 & 0.29 & 0.49 & 0.51 & 0.51 & 0.36 & 0.20 \\
\hline 0.34 & 0.21 & 0.37 & 0.43 & 0.45 & 0.29 & 0.06 \\
\hline 0.29 & 0.20 & 0.33 & 0.36 & 0.31 & 0.30 & 0.10 \\
\hline 0.41 & 0.25 & 0.46 & 0.47 & 0.43 & 0.40 & 0.39 \\
\hline 0.21 & 0.11 & 0.20 & 0.25 & 0.28 & 0.26 & 0.16 \\
\hline 0.38 & 0.25 & 0.42 & 0.46 & 0.47 & 0.34 & 0.16 \\
\hline 0.55 & 0.36 & 0.62 & 0.61 & 0.60 & 0.45 & 0.27 \\
\hline 0.31 & 0.23 & 0.45 & 0.47 & 0.42 & 0.42 & 0.18 \\
\hline 0.45 & 0.33 & 0.46 & 0.49 & 0.49 & 0.35 & 0.19 \\
\hline 0.35 & 0.00 & 0.36 & 0.41 & 0.41 & 0.33 & 0.17 \\
\hline 0.45 & 0.31 & 0.42 & 0.50 & 0.50 & 0.38 & 0.16 \\
\hline 0.05 & 0.05 & 0.08 & 0.06 & 0.04 & 0.05 & 0.02 \\
\hline 0.09 & 0.08 & 0.10 & 0.11 & 0.12 & 0.10 & 0.06 \\
\hline 0.16 & 0.14 & 0.18 & 0.16 & 0.15 & 0.18 & 0.18 \\
\hline 0.25 & 0.20 & 0.28 & 0.28 & 0.28 & 0.29 & 0.22 \\
\hline 0.41 & 0.39 & 0.41 & 0.41 & 0.45 & 0.44 & 0.49 \\
\hline 0.54 & 0.52 & 0.55 & 0.54 & 0.54 & 0.46 & 0.42 \\
\hline 0.65 & 0.67 & 0.65 & 0.64 & 0.64 & 0.58 & 0.57 \\
\hline 0.71 & 0.71 & 0.73 & 0.70 & 0.71 & 0.59 & 0.76 \\
\hline 0.78 & 0.88 & 0.78 & 0.77 & 0.78 & 0.78 & 0.40 \\
\hline 0.77 & 0.76 & 0.77 & 0.80 & 0.77 & 0.73 & 0.39 \\
\hline 0.81 & 0.84 & 0.80 & 0.84 & 0.81 & 0.66 & 0.73 \\
\hline 0.80 & 0.66 & 0.86 & 0.75 & 0.82 & 0.77 & 0.87 \\
\hline 0.84 & 0.89 & 0.85 & 0.86 & 0.82 & 0.79 & 0.42 \\
\hline 0.84 & 1.00 & 0.79 & 0.85 & 0.86 & 0.78 & 1.00 \\
\hline 0.77 & 0.77 & 0.87 & 0.78 & 0.72 & 0.78 & 0.22 \\
\hline 0.05 & 0.04 & 0.08 & 0.09 & 0.05 & 0.03 & 0.02 \\
\hline 0.08 & 0.08 & 0.09 & 0.10 & 0.11 & 0.08 & 0.05 \\
\hline 0.13 & 0.12 & 0.13 & 0.11 & 0.13 & 0.17 & 0.17 \\
\hline 0.22 & 0.18 & 0.26 & 0.22 & 0.25 & 0.25 & 0.19 \\
\hline 0.33 & 0.31 & 0.31 & 0.35 & 0.36 & 0.35 & 0.26 \\
\hline 0.40 & 0.37 & 0.41 & 0.39 & 0.44 & 0.38 & 0.40 \\
\hline 0.47 & 0.46 & 0.49 & 0.47 & 0.47 & 0.47 & 0.29 \\
\hline 0.50 & 0.48 & 0.51 & 0.51 & 0.51 & 0.43 & 0.36 \\
\hline 0.57 & 0.61 & 0.53 & 0.59 & 0.57 & 0.54 & 0.50 \\
\hline 0.61 & 0.56 & 0.62 & 0.61 & 0.61 & 0.68 & 0.21 \\
\hline 0.64 & 0.68 & 0.66 & 0.61 & 0.67 & 0.64 & 0.42 \\
\hline 0.66 & 0.61 & 0.61 & 0.67 & 0.72 & 0.71 & 0.81 \\
\hline 0.70 & 0.81 & 0.71 & 0.68 & 0.74 & 0.58 & 0.39 \\
\hline 0.73 & 0.65 & 0.72 & 0.76 & 0.72 & 0.83 & 0.71 \\
\hline 0.74 & 0.58 & 0.80 & 0.73 & 0.70 & 0.76 & 0.64 \\
\hline
\end{tabular}

Note: The sample consists of 31,825 workers ages 20 to 69 in 1997. Annual earnings are expressed in constant 2004 dollars.

Source: Urban Institute tabulations of the 1996 SIPP matched to the Detailed Earnings Record. 
TABLE A.3

PARTICIPATION RATES AMONG WORKERS AGES 20 TO 69 OFFERED EMPLOYER-SPONSORED TAX-DEFERRED RETIREMENT PLANS, BY AGE AND OTHER PERSONAL CHARACTERISTICS, 1997

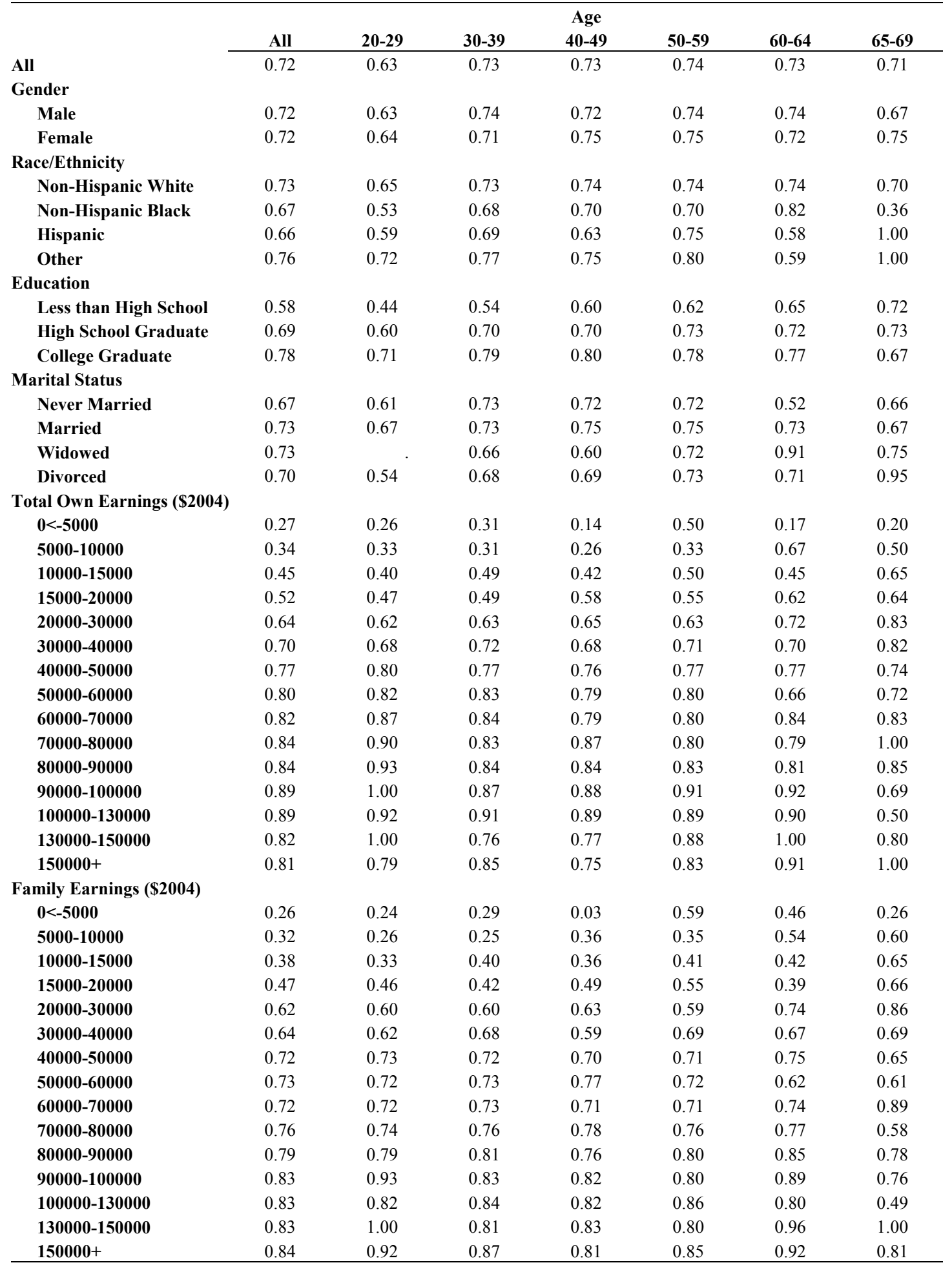

Note: The sample consists of 31,825 workers ages 20 to 69 in 1997. Annual earnings are expressed in constant 2004 dollars. Source: Urban Institute tabulations of the 1996 SIPP matched to the Detailed Earnings Record. 
TABLE A.4

AVERAGE REAL CONTRIBUTION AMOUNTS AMONG PLAN PARTICIPANTS AGES 20 TO 69 BY YEAR, AGE, AND OTHER PERSONAL CHARACTERISTICS, 1990 TO 2001

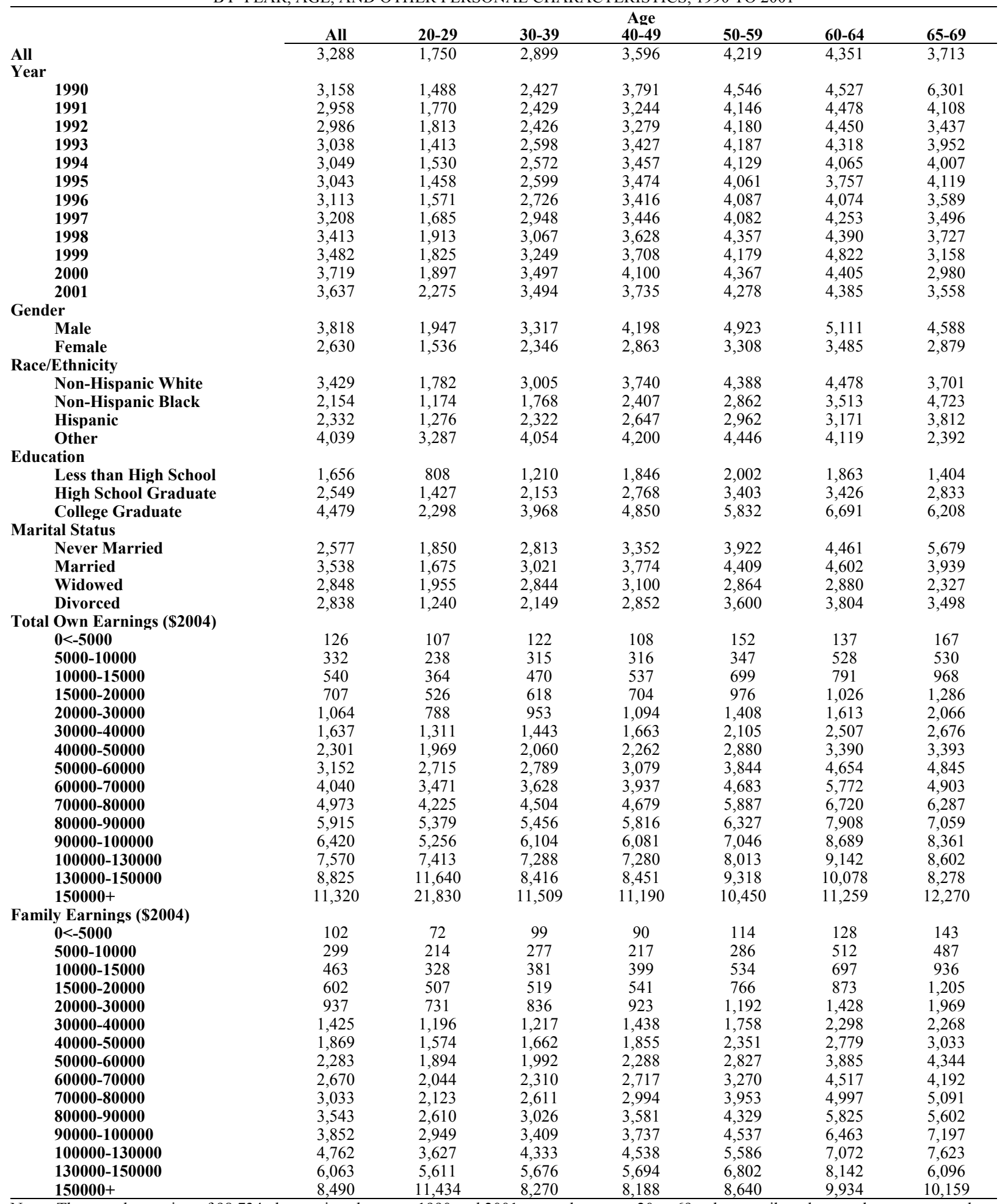

Note: The sample consists of 98,734 observations between 1990 and 2001 on workers ages 20 to 69, who contributed to employer-sponsored tax-deferred retirement plans. Annual earnings and contribution amounts are expressed in constant 2004 dollars.

Source: Urban Institute tabulations of the 1996 SIPP matched to the Detailed Earnings Record. 
TABLE A.5

AVERAGE CONTRIBUTION RATES AMONG PLAN PARTICIPANTS AGES 20 TO 69

BY YEAR, AGE, AND OTHER PERSONAL CHARACTERISTICS, 1990 TO 2001

All

1990

1991

1992

1993

1994

1995

1996

1997

1998

1999

2000

2001

Gender

Male

Female

Race/Ethnicity

Non-Hispanic White

Non-Hispanic Black

Hispanic

Other

Education

Less than High School

High School Graduate

College Graduate

Marital Status

Never Married

Married

Widowed

Divorced

Total Own Earnings (\$2004)

$0<-5000$

5000-10000

10000-15000

15000-20000

20000-30000

$30000-40000$

40000-50000

50000-60000

60000-70000

70000-80000

80000-90000

90000-100000

100000-130000

130000-150000

$150000+$

Family Earnings (\$2004)

$0<-5000$

5000-10000

10000-15000

15000-20000

20000-30000

$30000-40000$

40000-50000

50000-60000

$60000-70000$

70000-80000

80000-90000

90000-100000

100000-130000

130000-150000

$150000+$

(a)

( The contribution rate is defined as the and 2001 on workers

Source: Urban Institute tabulations of the 1996 SIPP matched to the Detailed Earnings Record.

$4.8 \%$

$5.0 \%$
$4.9 \%$
$5.0 \%$
$5.1 \%$
$5.2 \%$
$5.2 \%$
$5.3 \%$
$5.4 \%$
$5.5 \%$
$5.6 \%$
$5.6 \%$
$5.7 \%$

$3.6 \%$

$4.3 \%$

$5.3 \% \quad 4.1 \% \quad 4.9 \%$

$\begin{array}{lll}5.4 \% & 3.8 \% & 4.8 \%\end{array}$

$\begin{array}{lll}5.5 \% & 4.0 \% & 4.9 \%\end{array}$

$\begin{array}{lll}4.2 \% & 3.1 \% & 3.8 \% \\ 4.5 \% & 3.4 \% & 4.5 \%\end{array}$

$\begin{array}{lll}6.0 \% & 4.9 \% & 5.7 \%\end{array}$

$\begin{array}{llll}4.5 \% & 2.9 \% & 3.7 \% & 4.4 \% \\ 5.0 \% & 3.6 \% & 4.4 \% & 5.0 \% \\ 5.9 \% & 4.5 \% & 5.5 \% & 6.0 \%\end{array}$

$\begin{array}{lll}4.7 \% & 4.0 \% & 5.0 \% \\ 5.6 \% & 4.0 \% & 4.9 \%\end{array}$

$4.0 \% \quad 4.9 \%$

$\begin{array}{lll}4.9 \% & 3.6 \% & 4.8 \% \\ & & 4.0 \%\end{array}$

$\begin{array}{lll}4.3 \% & 3.1 \% & 4.1 \%\end{array}$

$\begin{array}{lll}4.2 \% & 2.8 \% & 3.7 \%\end{array}$

$\begin{array}{lll}4.0 \% & 3.0 \% & 3.5 \%\end{array}$

$\begin{array}{lll}4.2 \% & 3.1 \% & 3.7 \%\end{array}$

$\begin{array}{lll}4.7 \% & 3.8 \% & 4.1 \%\end{array}$

$5.1 \% \quad 4.4 \% \quad 4.6 \%$

$\begin{array}{lll}5.7 \% & 5.0 \% & 5.1 \% \\ 6.2 \% & 5.4 \% & 5.6 \%\end{array}$

$\begin{array}{lll}6.7 \% & 5.7 \% & 6.0 \%\end{array}$

$7.0 \% \quad 6.3 \%$

$6.8 \% \quad 5.5 \%$

$6.7 \% \quad 6.7 \%$

$6.4 \%$

$8.4 \%$

$6.4 \%$
$6.4 \%$

$$
6.5 \%
$$

$6.1 \%$

$\begin{array}{lll}4.0 \% & 3.0 \% & 3.6 \%\end{array}$

$\begin{array}{lll}3.8 \% & 2.6 \% & 3.0 \%\end{array}$

$\begin{array}{lll}3.5 \% & 2.9 \% & 3.0 \%\end{array}$

$\begin{array}{lll}3.8 \% & 3.0 \% & 3.4 \%\end{array}$

$\begin{array}{lll}4.3 \% & 3.6 \% & 3.7 \%\end{array}$

$4.7 \% \quad 4.0 \%$

$5.0 \% \quad 4.3 \%$

$\begin{array}{ll}5.2 \% & 4.2 \% \\ 5.4 \% & 4.2 \%\end{array}$

$5.8 \% \quad 4.8 \%$

$5.9 \% \quad 4.9 \%$

$5.3 \%$

$7.0 \%$

\section{Age}

40-49

60-64

65-69

$5.4 \%$

$6.5 \%$

$7.5 \%$

$7.6 \%$

$5.1 \%$

$5.0 \%$
$5.0 \%$

$5.0 \%$

$5.3 \%$

$5.3 \%$

$5.4 \%$

$5.4 \%$

$5.5 \%$

$5.5 \%$

$5.6 \%$

$5.7 \%$

$6.8 \%$

$7.5 \%$
$7.8 \%$$\quad 8.6 \%$

$7.8 \%$
$7.8 \%$

$7.6 \%$

$8.3 \%$

$\begin{array}{lll}6.5 \% & 7.4 \% & 8.1 \%\end{array}$

$\begin{array}{lll}6.4 \% & 6.8 \% & 8.3 \%\end{array}$

$\begin{array}{lll}6.5 \% & 7.3 \% & 7.7 \%\end{array}$

$\begin{array}{lll}6.5 \% & 7.3 \% & 7.6 \%\end{array}$

$\begin{array}{lll}6.6 \% & 7.3 \% & 7.4 \%\end{array}$

$\begin{array}{lll}6.5 \% & 7.5 \% & 7.4 \%\end{array}$

$\begin{array}{lll}6.5 \% & 7.6 \% & 7.0 \%\end{array}$

$\begin{array}{lll}6.5 \% & 7.6 \% & 7.3 \%\end{array}$

$5.4 \%$

$5.4 \%$

$6.3 \% \quad 7.0 \%$

$5.5 \%$

$4.3 \%$

$4.6 \%$

$6.2 \%$

$6.7 \%$

$5.1 \%$

$5.4 \%$

$6.9 \%$

$4.4 \%$

$5.0 \%$

$5.2 \%$

$\begin{array}{lll}5.2 \% & 5.3 \% & 5.9 \%\end{array}$

$6.9 \%$

$7.4 \%$
$8.3 \%$

$7.6 \%$

$\begin{array}{llll}5.5 \% & 6.3 \% & 7.0 \% & 6.5 \%\end{array}$

$5.5 \%$

$4.9 \%$

$6.7 \%$

$7.6 \%$

$\begin{array}{lll}5.7 \% & 6.9 \% & 7.3 \%\end{array}$

$7.8 \%$

$\begin{array}{lllllll}5.1 \% & 4.0 \% & 5.6 \% & 4.3 \% & 6.0 \% & 5.5 \% & 5.5 \%\end{array}$

$4.0 \%$

$4.2 \%$

$4.7 \%$

$5.4 \%$

$5.5 \%$

$5.5 \%$

$6.0 \%$

$6.4 \%$

$7.0 \%$

$7.2 \%$

$7.9 \%$

$7.4 \%$

$7.5 \%$

$7.1 \%$

$\begin{array}{llll}6.1 \% & 6.7 \% & 7.3 \% & 5.9 \% \\ 4.6 \% & 4.7 \% & 4.5 \% & 4.8 \%\end{array}$

$6.6 \%$

$6.3 \%$

$5.8 \%$

$6.4 \%$

$7.2 \%$

$7.5 \%$

$8.5 \%$

$8.9 \%$

$9.0 \%$

$9.3 \%$

$9.2 \%$

$8.0 \%$

$\begin{array}{llll}6.1 \% & 6.7 \% & 7.3 \% & 5.9 \% \\ 4.6 \% & 4.7 \% & 4.5 \% & 4.8 \%\end{array}$

$6.9 \%$

$7.7 \%$

$7.3 \%$

$8.4 \%$

$7.7 \%$

$7.5 \%$

$9.0 \%$

$7.7 \%$

$8.3 \%$

$8.3 \%$

$8.8 \%$

$7.8 \%$

$\begin{array}{lllllll}4.3 \% & 2.9 \% & 5.2 \% & 3.5 \% & 4.8 \% & 4.8 \% & 5.5 \%\end{array}$

$2.9 \%$

$4.0 \%$

$4.3 \%$

$4.6 \%$

$4.9 \%$

$5.4 \%$

$5.8 \%$

$6.0 \%$

$6.3 \%$

$6.8 \%$

$6.9 \%$

$7.0 \%$

$7.6 \%$
$7.9 \%$

$6.6 \%$

$6.6 \%$
$5.8 \%$

$5.1 \%$

$5.9 \%$

$7.0 \%$

$6.9 \%$

$8.1 \%$

$8.3 \%$

$8.1 \%$

$8.5 \%$

$9.2 \%$

$8.8 \%$
$8.7 \%$

$6.8 \%$

$7.7 \%$

$7.0 \%$

$8.4 \%$

$7.3 \%$

$7.6 \%$

$8.9 \%$

$8.1 \%$

$7.3 \%$

$7.8 \%$

$10.5 \%$

$\begin{array}{llll}6.2 \% & 7.6 \% & 8.8 \% & 8.7 \%\end{array}$

$6.7 \%$

$7.0 \%$

$6.9 \%$

$6.2 \%$

$6.1 \%$

20 to 69 , who contributed to employer-sponsored tax-

rd. 
TABLE A.6

DISTRIBUTION OF CONTRIBUTION RATES AMONG PLAN PARTICIPANTS AGES 20 TO 69 BY YEAR AND PERSONAL CHARACTERISTICS, 1990 TO 2001

Yea

ear

1990

1991

1992

1993

1994

1995

1996

1997

1998

1999

2000

2001

Gender

Male

Female

Race/Ethnicity

Non-Hispanic White

Non-Hispanic Black

Hispanic

Other

Education

Less than High School

High School Graduate

College Graduate

Marital Status

Never Married

Married

Widowed

Divorced

Total Own Earnings (\$2004)

$0<-5000$

5000-10000

10000-15000

15000-20000

20000-30000

30000-40000

40000-50000

50000-60000

60000-70000

70000-80000

80000-90000

90000-100000

100000-130000

130000-150000

$150000+$

Family Earnings (\$2004)

$0<-5000$

5000-10000

10000-15000

15000-20000

20000-30000

30000-40000

40000-50000

50000-60000

60000-70000

70000-80000

80000-90000

90000-100000

100000-130000

130000-150000

$150000+$

Contribution Rate (\%)

\begin{tabular}{cccccccccc} 
All & $\mathbf{0}<=\mathbf{2}$ & $\mathbf{2}<=\mathbf{4}$ & $\mathbf{4}<=\mathbf{6}$ & $\mathbf{6}<=\mathbf{8}$ & $\mathbf{8}<=\mathbf{1 0}$ & $\mathbf{1 0}<=\mathbf{1 2}$ & $\mathbf{1 2}<=\mathbf{1 4}$ & $\mathbf{1 4 +}$ \\
\hline 100 & 18 & 24 & 26 & 11 & 10 & 4 & 4 & 2
\end{tabular}

$\begin{array}{lllllllll}100 & 20 & 25 & 27 & 10 & 8 & 4 & 3 & 3 \\ 100 & 21 & 25 & 28 & 10 & 8 & 4 & 2 & 2 \\ 100 & 19 & 26 & 28 & 10 & 8 & 4 & 3 & 2 \\ 100 & 19 & 26 & 27 & 10 & 9 & 4 & 3 & 2 \\ 100 & 18 & 25 & 26 & 11 & 10 & 4 & 3 & 2 \\ 100 & 19 & 24 & 27 & 10 & 10 & 4 & 4 & 2 \\ 100 & 17 & 24 & 27 & 11 & 10 & 4 & 4 & 2 \\ 100 & 18 & 24 & 26 & 11 & 10 & 5 & 4 & 2 \\ 100 & 17 & 23 & 26 & 12 & 11 & 5 & 4 & 2 \\ 100 & 16 & 23 & 26 & 12 & 11 & 5 & 5 & 2 \\ 100 & 17 & 23 & 25 & 12 & 11 & 5 & 5 & 3 \\ 100 & 16 & 22 & 26 & 12 & 12 & 5 & 5 & 2\end{array}$

$\begin{array}{lllllllll}100 & 17 & 23 & 28 & 12 & 11 & 4 & 4 & 1 \\ 100 & 19 & 25 & 25 & 10 & 10 & 4 & 5 & 3\end{array}$

$\begin{array}{lllllllll}100 & 17 & 23 & 27 & 11 & 11 & 5 & 4 & 3\end{array}$

$100 \quad 26 \quad 30 \quad 31$

100

100

100

100

24

30

25

10

13

7
8

13

$\begin{array}{lccccc}23 & 9 & 9 & 2 & 2 & 1 \\ 27 & 10 & 9 & 4 & 3 & 2 \\ 27 & 13 & 12 & 6 & 5 & 3\end{array}$

1

$\begin{array}{lllllllll}23 & 26 & 25 & 9 & 9 & 4 & 3 & 1 & 0 \\ 16 & 23 & 27 & 12 & 11 & 5 & 4 & 3 & 0 \\ 17 & 23 & 22 & 10 & 9 & 5 & 8 & 5 & 0 \\ 20 & 26 & 25 & 11 & 9 & 3 & 3 & 2 & 0\end{array}$

Note: The sample consists of 98,734 observations between 1990 and 2001 on workers ages 20 to 69, who contributed to employersponsored tax-deferred retirement plans. The contribution rate is defined as the annual contribution amount divided by total annual earnings.

Source: Urban Institute tabulations of the 1996 SIPP matched to the Detailed Earnings Record. 
TABLE A.7

SUMMARY STATISTICS FOR LOGISTIC REGRESSION SAMPLE

\begin{tabular}{|c|c|c|c|c|}
\hline & Mean & $\begin{array}{l}\text { Standard } \\
\text { Deviation }\end{array}$ & Minimum & Maximum \\
\hline Contribute to deferred plan & 0.484 & 0.500 & 0 & 1 \\
\hline Married & 0.665 & 0.472 & 0 & 1 \\
\hline Two earners & 0.547 & 0.498 & 0 & 1 \\
\hline Number of dependents & 0.779 & 1.057 & 0 & 8 \\
\hline Have a baby this year & 0.039 & 0.193 & 0 & 1 \\
\hline Have a baby last year & 0.041 & 0.198 & 0 & 1 \\
\hline Purchase a home this year & 0.029 & 0.169 & 0 & 1 \\
\hline Purchase a home last year & 0.027 & 0.163 & 0 & 1 \\
\hline Own a home & 0.322 & 0.467 & 0 & 1 \\
\hline Become work limited this year & 0.002 & 0.045 & 0 & 1 \\
\hline Become work limited last year & 0.002 & 0.048 & 0 & 1 \\
\hline Log of total earnings & 10.650 & 1.551 & 0 & 16.363 \\
\hline Become divorced this year & 0.013 & 0.113 & 0 & 1 \\
\hline Become widowed this year & 0.001 & 0.038 & 0 & 1 \\
\hline Get married this year & 0.030 & 0.170 & 0 & 1 \\
\hline Spouse contributes to a DC plan & 0.179 & 0.383 & 0 & 1 \\
\hline Spouse's contribution rate (contribution/earnings) & 0.010 & 0.026 & 0 & 0.5 \\
\hline Employer contributes to plan & 0.607 & 0.488 & 0 & 1 \\
\hline Age & 38.977 & 10.371 & 20 & 69 \\
\hline Age squared & 1626.740 & 844.109 & 400 & 4761 \\
\hline Have a DB plan & 0.412 & 0.492 & 0 & 1 \\
\hline Currently work limited & 0.025 & 0.157 & 0 & 1 \\
\hline Spouse currently work limited & 0.029 & 0.168 & 0 & 1 \\
\hline Gets a job this year after unemployment & 0.015 & 0.122 & 0 & 1 \\
\hline Spouse gets a job this year after unemployment & 0.016 & 0.125 & 0 & 1 \\
\hline Change jobs this year & 0.253 & 0.435 & 0 & 1 \\
\hline Spouse changes jobs this year & 0.228 & 0.420 & 0 & 1 \\
\hline Change jobs last year & 0.157 & 0.364 & 0 & 1 \\
\hline Spouse changes jobs last year & 0.141 & 0.348 & 0 & 1 \\
\hline Spouses loses a job this year & 0.018 & 0.133 & 0 & 1 \\
\hline Spouse begins to contribute to DC plan this year & 0.026 & 0.158 & 0 & 1 \\
\hline Can borrow from pension plan & 0.372 & 0.483 & 0 & 1 \\
\hline
\end{tabular}


Real Deferred Contributions (\$2004)

Married

Two earners

Number of dependents

Have a baby this year

Have a baby last year

Purchase a home this year

Purchase a home last year

Own a home

Become work limited this year

Become work limited last year

Log of total earnings

Become divorced this year

Become widowed this year

Get married this year

Spouse contributes to a DC plan

Spouse's contribution rate (contribution/earnings)

Employer contributes to plan

Age

Age squared

Have a DB plan

Currently work limited

Spouse currently work limited

Gets a job this year after unemployment

Spouse gets a job this year after unemployment

Change jobs this year

Spouse changes jobs this year

Change jobs last year

Spouse changes jobs last year

Spouses loses a job this year

Spouse begins to contribute to DC plan this year

Can borrow from pension plan

Age 30-39

Age 40-49

Age 50-59

Age 60-69

Note: The sample consists of 43,830 person-year observations between 19 to 69 who contributed to employer-sponsored tax-deferred retirement plans.

Source: Urban Institute tabulations of the 1996 SIPP matched to the Detailed Earnings Record.
Standard

\begin{tabular}{lrrr} 
Mean & Deviation & Minimum & Maximum \\
\hline 3143.120 & 3473.950 & 0.241 & 246006.4
\end{tabular}

$0.719 \quad 0.450$

$0.587 \quad 0.492$

$0.796 \quad 1.048$

$0.038 \quad 0.192$

$0.040 \quad 0.195$

$0.035 \quad 0.183$

$0.034 \quad 0.181$

$0.396 \quad 0.489$

$0.002 \quad 0.045$

$0.002 \quad 0.047$

$11.112 \quad 0.635$

$0.012 \quad 0.107$

$0.001 \quad 0.038$

$0.026 \quad 0.159$

$0.230 \quad 0.421$

$0.014 \quad 0.031$

$0.610 \quad 0.488$

$\begin{array}{ll}41.105 & 9.700\end{array}$

825.024

$0.454 \quad 0.498$

$0.023 \quad 0.149$

$0.032 \quad 0.176$

$0.002 \quad 0.044$

$0.016 \quad 0.127$

$0.178 \quad 0.382$

$0.209 \quad 0.407$

$0.135 \quad 0.342$

$0.135 \quad 0.342$

$0.019 \quad 0.138$

$0.032 \quad 0.175$

$0.389 \quad 0.487$

$0.333 \quad 0.471$

$0.333 \quad 0.471$

$0.177 \quad 0.382$

$0.031 \quad 0.175$

$\begin{array}{rr}241 & 246006.4 \\ 0 & 1\end{array}$

$0 \quad 1$

$\begin{array}{ll}0 & 7\end{array}$

$0 \quad 1$

$0 \quad 1$

$0 \quad 1$

$\begin{array}{ll}0 & 1\end{array}$

$\begin{array}{ll}0 & 1 \\ 0 & 1 \\ 0 & 1\end{array}$

$4.621 \quad 16.363$

$0 \quad 1$

0 1

$\begin{array}{ll}0 & 1\end{array}$

$\begin{array}{ll}0 & 1\end{array}$

$\begin{array}{ll}0 & 0.5\end{array}$

$0 \quad 1$

$20 \quad 69$

$400 \quad 4761$

$0 \quad 1$

$0 \quad 1$

$\begin{array}{ll}0 & 1\end{array}$

$\begin{array}{ll}0 & 1 \\ 0 & 1\end{array}$

$0 \quad 1$

$0 \quad 1$

$0 \quad 1$

0 1

$\begin{array}{ll}0 & 1\end{array}$

$\begin{array}{ll}0 & 1\end{array}$

$\begin{array}{ll}0 & 1\end{array}$

$\begin{array}{ll}0 & 1\end{array}$

$\begin{array}{ll}0 & 1\end{array}$

$\begin{array}{ll}0 & 1\end{array}$

$\begin{array}{ll}0 & 1\end{array}$

20 


\section{RECENT WORKING PAPERS FROM THE \\ CEnTER FOR RETIREMEnT RESEARCH AT Boston College}

Providing Guarantees in Social Security

Karen E. Smith, C. Eugene Steuerle, and Pablo Montagnes, August 2004

Deferring Income in Employer-Sponsored Retirement Plans: The Dynamics of Participant Contributions

Karen E. Smith, Richard W. Johnson, and Leslie A. Muller, August 2004

Reform Model Two of the President's Commission to Strengthen Social Security: Distributional Outcomes Under Different Economic and Behavioral Assumptions Melissa M. Favreault, Joshua H. Goldwyn, Karen E. Smith, Lawrence H. Thompson, Cori E. Uccello, and Sheila R. Zedlewski, August 2004

An Analysis of How Individuals React to Market Returns in One 401(k) Plan Julie Agnew, April 2004

The Effects of Health Insurance and Self-Insurance on Retirement Behavior Eric French and John Bailey Jones, April 2004

Valuing Assets in Retirement Saving Accounts James M. Poterba, April 2004

Lifetime Earnings, Social Security Benefits, and the Adequacy of Retirement Wealth Accumulation

Eric M. Engen, William G. Gale, and Cori Uccello, April 2004

The Effect of Social Security on Divorce and Remarriage Behavior Stacy Dickert-Conlin and Cristian Meghea, April 2004

Household Demand for Variable Annuities

Jeffrey R. Brown and James M. Poterba, March 2004

Lessons for an Aging Society: The Political Sustainability of Social Security Systems Vincenzo Galasso and Paola Profeta, March 2004

Choice and Other Determinants of Employee Contributions to Defined Contribution Plans

Leslie E. Papke, March 2004

All working papers are available on the Center for Retirement Research website (http://www.bc.edu/crr) and can be requested by e-mail (crr@ bc.edu) or phone (617-552-1762). 